\title{
FOREIGNERS KNOCKING ON THE DOOR: TRADE IN CHINA DURING THE TREATY PORT ERA
}

\author{
Wolfgang Keller \\ Javier Andres Santiago \\ Carol H. Shiue \\ Working Paper 21886 \\ http://www.nber.org/papers/w21886 \\ NATIONAL BUREAU OF ECONOMIC RESEARCH \\ 1050 Massachusetts Avenue \\ Cambridge, MA 02138 \\ January 2016
}

We thank the editor (Kris Mitchener), two anonymous referees, and Greg Clark, Debin Ma, Kevin O'Rourke, Ferdinand Rauch, Noam Yuchtman, as well as workshop participants at the 2015 All UC Group in Economic History Conference, Berkeley, and the 2016 CEPR Economic History Symposium, Dublin, for useful comments. Bill Ridley provided excellent research assistance. Keller and Shiue gratefully acknowledge support by the National Science Foundation (grant SES 1124426). The views expressed herein are those of the authors and do not necessarily reflect the views of the National Bureau of Economic Research.

NBER working papers are circulated for discussion and comment purposes. They have not been peer-reviewed or been subject to the review by the NBER Board of Directors that accompanies official NBER publications.

(C) 2016 by Wolfgang Keller, Javier Andres Santiago, and Carol H. Shiue. All rights reserved. Short sections of text, not to exceed two paragraphs, may be quoted without explicit permission provided that full credit, including $\odot$ notice, is given to the source. 
Foreigners Knocking on the Door: Trade in China During the Treaty Port Era

Wolfgang Keller, Javier Andres Santiago, and Carol H. Shiue

NBER Working Paper No. 21886

January 2016, Revised August 2016

JEL No. F11,F15,N15,O1

\begin{abstract}
$\underline{\text { ABSTRACT }}$
Uneven development within countries suggests that domestic trade frictions are important. Trade flows within a country, however, are rarely observed. We employ a new dataset on trade between fifteen Chinese treaty ports to examine the importance of domestic frictions around the year 1900. The distribution of welfare effects depends on each port's productivity and factor costs, China's economic geography as it influences trade costs, as well as the degree of regional diversity in production, which increases the potential gains from trade. We utilize this framework to quantify the size and distribution of welfare effects resulting from new technology and lower trade costs. Domestic trade frictions turn out to be substantial, far from the frictionless world that is commonly assumed. Moreover, geographic barriers loom large in shaping the welfare gains from technology improvements and trade cost reductions. We find, however, that an important explanation for why there was a limit to what could be gained through increased domes- tic trade was that the differences in productivity across regions of China in the 19th century were relatively low.
\end{abstract}

Wolfgang Keller

Department of Economics

University of Colorado at Boulder

Boulder, CO 80309-0256

and NBER

Wolfgang.Keller@colorado.edu

Javier Andres Santiago

Department of Economics

University of Colorado at Boulder

Boulder, CO 80309

javier.andressantiago@colorado.edu
Carol H. Shiue

Department of Economics

University of Colorado at Boulder

Boulder, CO 80309

and NBER

carol.shiue@colorado.edu 


\section{Introduction}

Starting in mid-19th century, under military action from Western countries, China opened an increasing number of ports to foreign traders. These ports were the conduits of goods, but they were also the carriers of Western influence. During the Treaty Port Era (1842-1943), foreigners introduced steam ships to China, dredged harbors, ran the postal system, set up Western courts, and were involved in numerous other parts of the Chinese economy. One area in which Western presence was particularly important was the customs system, which from 1859 on operated under the auspices of the Western-led Chinese Maritime Customs Service (CMCS). We know about trade that crosses a country's border because it is typically there that tariffs are assessed. ${ }^{1}$ In contrast, very little is known about trade within countries, to the point that in mainstream analysis countries have until recently been taken as dimensionless points in space (Krugman 2010). The Treaty Port Era provides a unique opportunity to study trade within a country's borders because CMCS statistics record all goods entering and leaving individual ports. In this paper, we examine how internal trade within China has shaped the spread of the foreign influence throughout China.

We construct a new, commodity-level, dataset for fifteen major treaty ports to estimate our model, based on Eaton and Kortum (2002), for China in the year $1904 .^{2}$ The data pins down a small number of parameters that govern the magnitude of the general-equilibrium trade responses to shocks in one or more regions. We utilize this framework to quantify the size and distribution of welfare effects resulting from new technology and lower trade costs. We show that the distribution of welfare effects depends critically on each port's productivity, China's economic geography (because it affects trade costs), and the extent of regional diversity in production (because of how that shapes the potential gains from trade).

\footnotetext{
${ }^{1}$ The paucity of information on internal trade is related to the absence of internal trade taxes; e.g. the Import-Export Clause, Article 1, Section 10, Clause 2 of the U.S. Constitution.

${ }^{2}$ We choose 1904 because this is the last year for which CMCS statistics report bilateral trade between treaty ports. Below we also discuss results for two earlier cross sections, namely in 1879 and in 1899 .
} 
Specifically, a 20\% increase in Shanghai's productivity raises welfare in Shanghai by about $1.5 \%$; because of trade, however, total welfare gains accrue not only to Shanghai (which receives about $40 \%$ of total), but also Ningbo, Chinkiang, and Wuhu, located in the vicinity of Shanghai (28\% of total). In addition, since factor costs, income, and production patterns respond endogenously, welfare in some ports can actually fall when Shanghai's technology improves, as it does in the relatively distant Tianjin.

There are two main findings. First, we show that through trade, a change in any one of the treaty ports has an impact throughout China; it is not bottled up within the areas of immediate foreign influence. Technology, factor costs and trade frictions all play a role for the welfare gains from trade, but it is trade frictions, as determined by China's economic geography, that are found to be central for the distribution of the welfare gains from trade across regions. Second, across China during the Treaty Port Era, the evidence for regional diversity in productivity across goods is smaller than for today's international trade between high-income countries. This puts a lid on the aggregate size of welfare gains because differences in productivity across goods-comparative advantage-is the source of the gains from trade in our analysis.

There has been a recent resurgence of interest in China's trade during the Treaty Port Era (Keller, Li, and Shiue 2011, 2013, Mitchener and Yan 2014). ${ }^{3}$ In contrast to Mitchener and Yan's (2014) analysis of the factor price effects of China's foreign trade we focus on China's domestic trade in locally-produced goods. For one, domestic trade is typically large relative to foreign trade. ${ }^{4}$ In addition, this is a rare case where domestic frictions can be quantified, important not least of all in light of how uneven China's economic development tends to be across hinterland and coastal regions - in the past as well as today. ${ }^{5}$ Our analysis complements

\footnotetext{
${ }^{3}$ Earlier contributions include Hsiao (1974) and Lyons (2003).

${ }^{4}$ For example, Shanghai's exports to the single treaty port of Yantai (Chefoo) were comparable in size to Shanghai's exports to the country of Great Britain; for the year 1904, see CMC (2001a), Vol. 39.

${ }^{5}$ Recent work stresses that domestic trade frictions are critical for our models to fit the data; for example, Ramondo, Rodriguez-Clare, and Saborio (2016) calculate that without accounting for domestic
} 
earlier work on China's internal trade in this era (Kose 1994, 2005; Keller, Li, and Shiue 2012) by quantifying the size and distribution of the welfare gains from trade.

A large literature is concerned with the implications of Western influence in China during the 19 th and early 20 th centuries. ${ }^{6}$ Although early views tended to view the foreign presence negatively, some authors cited positive demonstration effects $(\text { Feuerwerker } 1983)^{7}$ and recent work note other positive treaty port influences (So and Myers 2011, Jia 2014). We do not estimate the causal effect of treaty port opening. Rather, given the size and structure of domestic trade frictions around 1900, we are interested in how inter-regional trade shapes welfare outcomes as regions experience technological and trade cost change. To do this, we take a counterfactual approach to document how, in this setting, technology improvements and trade cost declines were related to the substantial increase in China's trade in the late 19 th century. ${ }^{8}$ Some readers might want to view this as tracing out an indirect effect of the foreign opening, as our estimate on the geographic scope of the Western impact in China is from the vantage point of a trade model.

Our analysis is part of a rapidly growing literature studying historical economies with the help of general-equilibrium trade models. Whether it is relative factor prices that are of interest, as in the Heckscher-Ohlin analyses of O'Rourke and Williamson (1994, 1999) and Mitchener and Yan (2014), or aggregate welfare effects and trade costs as in our Ricardian analysis, general-equilibrium trade models provide a well-defined framework in which to interpret historical data, test sharp hypotheses, or conduct counterfactual analyses. A key contribution here is that in contrast to most studies employing general-equilibrium trade models,

trade frictions Denmark's per-capita income relative to the U.S. is predicted to be $34 \%$, far off what is in the data (94\%), while with domestic trade frictions this rises to $81 \%$.

${ }^{6}$ Morse (1926) and Fairbank (1978) provide detailed historical accounts of China's treaty port era.

${ }^{7}$ Dernberger (1975) summarizes the earlier literature. See also Rawski (1989), Richardson (1999).

${ }^{8}$ We recognize that domestic trade frictions in the year 1904 do not only reflect the mid-century Western opening but also China's development in the centuries before; the integration of China's commodity markets in the second half of the 18th century, for example, was roughly on par with that in Western Europe (Shiue and Keller 2007). 
the figures on domestic trade we employ are data, not estimates. ${ }^{9}$ Closest to our paper in this respect may be Donaldson (2015). ${ }^{10}$ Our paper complements his analysis of agricultural income gains due to railroads in colonial India, although we focus on trade via ships of a broader set of commodities. While the quality of the data on China does not match that for British India, we know the precise volume of the ship trade, in contrast to British India where only data on the location of railroad tracks and the total trade volume is available.

\section{Historical Background: Trajectories from the Past}

After her defeat in the First Opium War (1840 - 1842), China signed the Treaty of Nanjing (1842) which expanded the rights of Western countries to trade at a total of five Chinese ports, four more than the one (Canton) that they had been allowed. Other stipulations included that Hong Kong would become a British colony, and that foreigners would be subject to the laws of their own countries, as opposed to Chinese law (extraterritoriality). Additional ports were opened to trade with the West in subsequent years. Given that the post-1842 increase in trade did not live up to Western expectations, and that trade taxes went largely unpaid during the Taiping Rebellion (1850-64), in the year 1854 it was decided that China's customs system would be run by Western officials who formally would be employed by China's central government. The organization that was founded for this task was the Chinese Maritime Customs Service (CMCS; Imperial Maritime Customs Service before 1911), with Horatio Nelson Lay as its first leader. Operations of the CMCS began in full in the year 1859 in Shanghai, with other ports following over time. Robert Hart became Inspector-General of the CMCS in the year 1863. His influence shaped the organization of the CMC and China's trade opening for decades to come.

While this paper is focused on the welfare effects of China's domestic trade around

\footnotetext{
${ }^{9}$ Typically, domestic trade flows are estimated based on distance, as in Ramondo, Rodriguez-Clare, and Saborio (2016) for example.

${ }^{10}$ See also Fajgelbaum and Redding (2015)'s related study on Argentina.
} 
the turn of the century, given the unprecedented growth of trade and foreign direct investment in China since 1978 it is important to ask how the 19th century fits in with China's long-run development (Brandt, Ma, and Rawski 2014). For the following analysis we focus on Shanghai, which is the largest port in the world today by several measures (see Keller, Li, and Shiue 2013).

We begin by considering foreign trade. In Figure 1, we show Shanghai's exports to the European continent between 1865 and 2009. Extrapolating the trend from

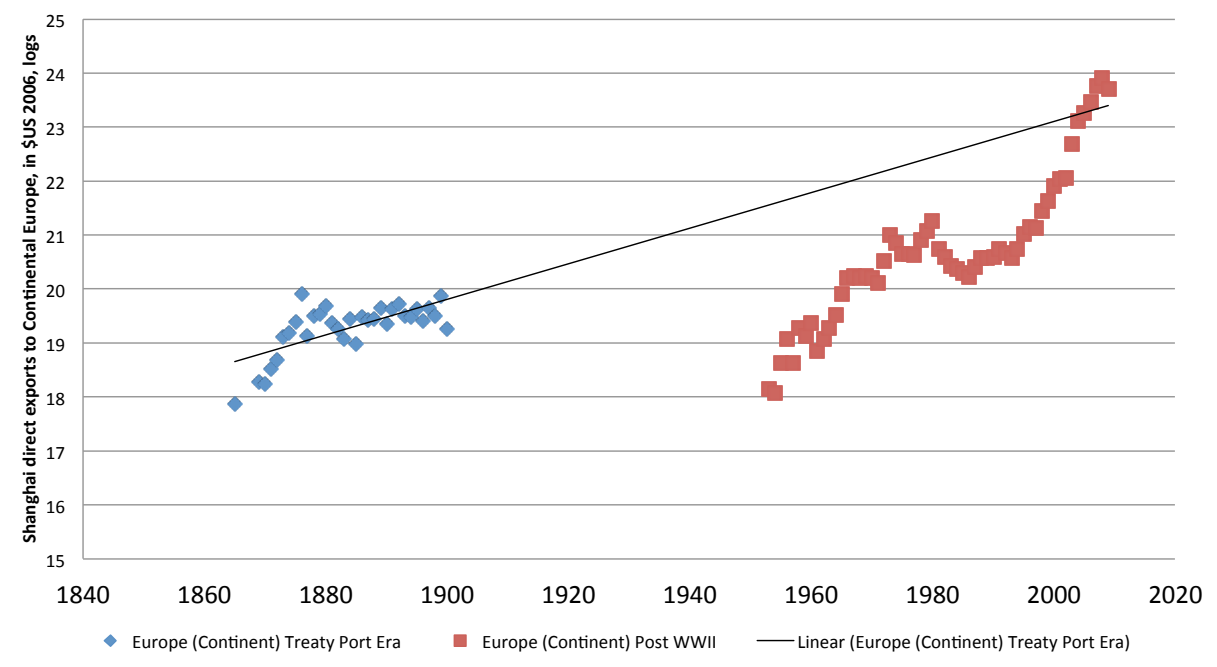

Figure 1. Shanghai's Exports to the European Continent, 1865 to 2009

Source: Chinese Maritime Customs CMC (2001a).

1865 to 1900 , we see that the level of Shanghai's exports in the early 2000s was close to what one would have predicted based on the 19th century trend. Additional results for all countries and the early 20th century, as well as on imports, are presented in Keller, Li, and Shiue (2013). Figure 2 shows that while French foreign direct investment (FDI) in Shanghai is well below what a simple extrapolation of the 1872-1921 trend would yield, the relatively fast growth of FDI recently is consistent with a return to historical trend. ${ }^{11}$ Figure 3 shows

${ }^{11}$ Part of the difference in FDI levels for the two sub-periods may be due to the fact that we employ 


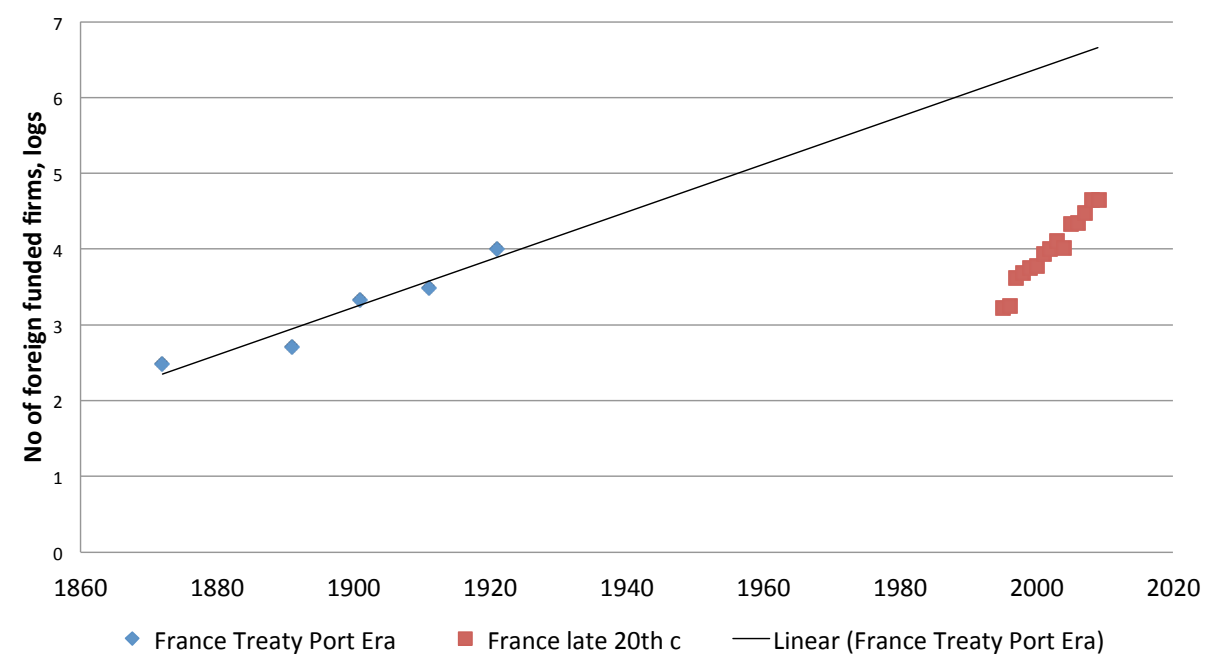

Figure 2. French FDI in Shanghai

Source: Chinese Maritime Customs CMC (2001a).

that the number of Germans in Shanghai today is quite close to what one would expect based on extrapolating the 19th century trend.

Overall, these findings suggest that although the post-1949 era differs from the 19 th and early 20th centuries in that China had become a fully sovereign country, it is hard to ignore the historical trajectories to which China appears to be returning to now. To put this differently, it will be much harder to predict China's trajectory over the next four decades than it was to predict where China was going for the roughly four decades since 1978.

We now turn to our analysis of China's domestic trade during the Treaty Port Era, beginning with our theoretical framework.

the number of foreign firms in the historical and the value of the FDI stock in the more recent period; see Keller, Li, and Shiue (2013). 


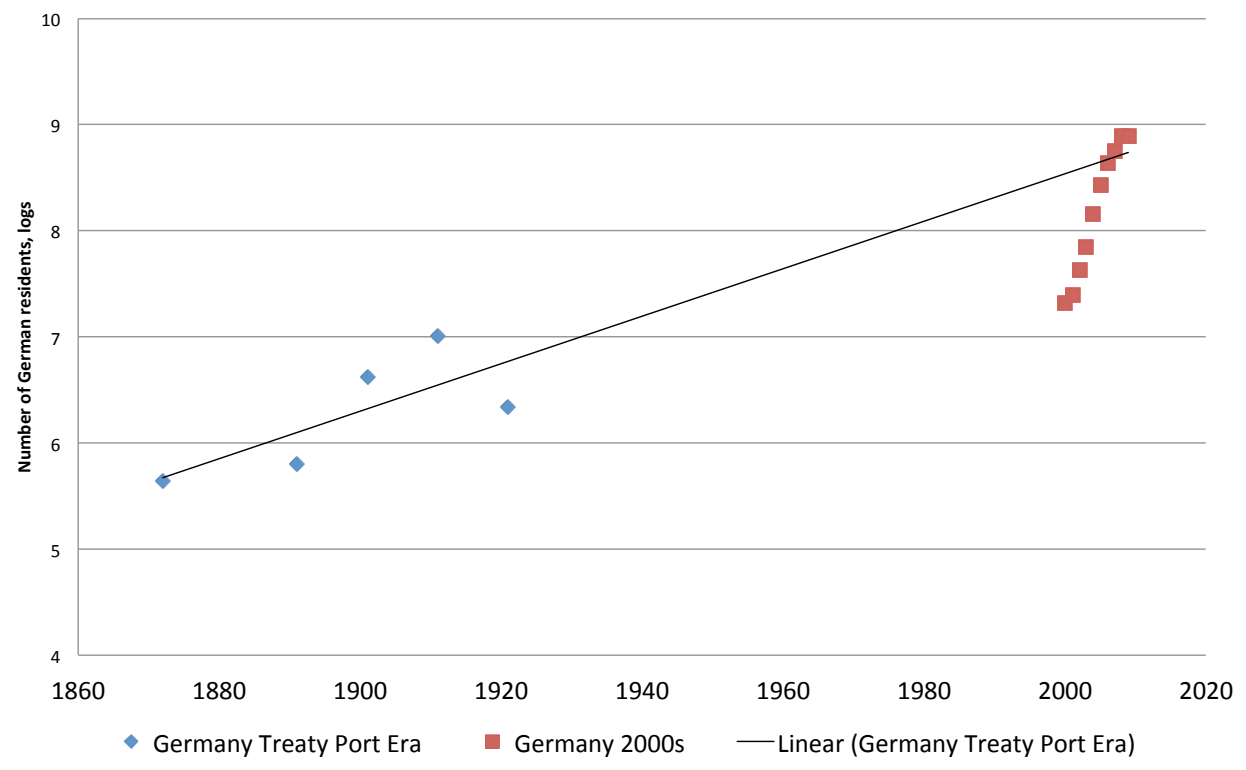

Figure 3. German Population in Shanghai

Source: Chinese Maritime Customs CMC (2001a).

\section{Theoretical framework}

Our analysis is based on the Ricardian trade model of Eaton and Kortum (2002). This section sketches the main features of the model with an emphasis on its empirical implications. For a full description including proofs and extensions, the interested reader is referred to Eaton and Kortum (2002).

We consider an economy consisting of $N$ regions. In the empirical analysis below these regions will be the customs districts of fifteen treaty ports in China. In each region, firms produce a continuum of goods $j \in[0,1]$. Goods can be traded across regions, though trade is costly. Bilateral trade costs between region $n$ and $i$ are denoted by $d_{n i}$, where $n$ and $i$ are destination (importer) and source (exporter) region, respectively. A convenient formulation of trade costs is that costs are in terms of the goods themselves: trade costs of $d_{n i}$ mean that $d$ units of the good have to be shipped from $i$ in order for one unit to arrive in region $n$. We 
assume that interregional trade costs are positive, $d_{n i}>1$ if $n \neq i$, while within a region trade costs are zero $\left(d_{i i}=1, \forall i\right) .{ }^{12}$ Given interregional trade flows and other data, these trade costs will be estimated in the context of the model. Trade costs capture the internal geography of China, including the geographic distance between $n$ and $i$, and in the empirics below we allow for additional influences.

Consumers in all regions have identical preferences and maximize the following utility function subject to a standard budget constraint:

$$
U=\left[\int_{0}^{1} Q(j)^{(\sigma-1) / \sigma}\right]^{\sigma /(\sigma-1)}
$$

where $Q(j)$ is the quantity of good $\mathrm{j}$ consumed, and $\sigma>0$ is the elasticity of substitution between each pair of goods.

Production technology varies across regions and goods; we denote region $i$ 's efficiency in the production of good $j$ by $z_{i}(j)$. The efficiency is stochastic and, dropping the $j$ index for ease of notation, it is drawn from the following (Fréchet) distribution function:

$$
F_{i}(z)=e^{-T_{i} z^{-\theta}}
$$

with $T_{i}>0$ and $\theta>1$. The technology parameter $T_{i}$ is region $i$-specific and shifts the distribution of the efficiency draws: a higher value of $T_{i}$ increases the probability of drawing a higher level of efficiency. In the context of a Ricardian model, $T_{i}$ is hence a measure of the absolute advantage of a region. In contrast, the parameter $\theta$ determines the variance of the efficiency draws. As $\theta$ increases, the variance of productivity draws falls, until in the limit, with $\theta$ tending to infinity, each draw in region $i$ has the same efficiency, which is governed by $T_{i}$. This means that the relative efficiency across goods-the production of good $j$ compared to

\footnotetext{
${ }^{12}$ We have also considered positive within-region trade costs, as discussed in Appendix C. Standard assumptions for within-region trade costs (see Appendix C) have only a minor impact on our empirical findings.
} 
that of good $j$ '-does not differ across regions, and hence there are no gains from trade in this model. Thus, $\theta$ governs the strength of comparative advantage, with the gains from specialization higher the lower is $\theta$. The formulation in equation (2) describes production efficiency with $N+1$ parameters, one for each region's absolute advantage and a variance parameter that we assume is common to all regions. We will estimate these key parameters below.

With competitive firms and constant returns to production yielding a unit input cost of $c_{i}$, the price a buyer in region $n$ would pay for 1 unit of good $j$ produced in region $i$ is:

$$
p_{n i}(j)=\left(\frac{c_{i}}{z_{i}(j)}\right) d_{n i}
$$

The price will be higher the higher are input costs $\left(c_{i}\right)$, the lower is productivity $\left(z_{i}(j)\right)$, and the larger the trade costs $\left(d_{n i}\right)$. The distribution of unit prices of region $i$ produced goods that are offered in region $n$ can be shown to equal:

$$
G_{n i}(p)=\operatorname{Pr}\left(P_{n i} \leq p\right)=1-\exp \left(-\left[T_{i}\left(c_{i} d_{n i}\right)^{-\theta}\right] p^{\theta}\right)
$$

which indicates that for any value $p$ the chance of a region i-produced good to undercut this $p$ is increasing in region i's absolute advantage $\left(T_{i}\right)$ and decreasing in both region $i$ 's input cost $\left(c_{i}\right.$, such as wages $)$ and trade costs $\left(d_{n i}\right)$. A consumer in region $n$ is faced from every region $i$ (including his domestic region $n$ ) with a distribution of prices according to (4), and the consumer will choose to buy the good from the cheapest source. The distribution of the lowest price in $n$ is:

$$
G_{n}(p)=\operatorname{Pr}\left(P_{n} \leq p\right)=1-\exp \left(-\Phi_{n} p^{\theta}\right)
$$

where $\Phi_{n}=\sum_{i=1}^{N} T_{i}\left(c_{i} d_{n i}\right)^{-\theta}$. Notice that actual purchases in $n$ depend not only on $n$ 's own technology and input costs but also on those of other regions, as well as region $n$ 's geographic barriers to all potential trade partner (reflected in 
the $\left.d_{n i}\right)$. Gains from trade arise if foreign production inclusive of shipping has a lower unit price than buying domestically, and the more potential exporters there are the (weakly) lower the price. Formally, the price index corresponding to the utility function in (1), $p_{n}$, is falling in $\Phi_{n}$. Moreover, it does so more strongly the lower is $\theta$, because lower $\theta$ raises the chance of an extraordinarily high efficiency draw in some region.

We now turn to the implications of our model for bilateral trade. First, the probability that region $i$ is the cheapest source of a good for destination $n$ can be shown to equal

$$
\pi_{n i}=\frac{T_{i}\left(c_{i} d_{n i}\right)^{-\theta}}{\Phi_{n}}
$$

which is intuitive because in this expression, region $i$ 's (input- and trade costadjusted) absolute advantage in the numerator is compared to the (adjusted) absolute advantages of all $N$ regions in the denominator. With a continuum of goods one can apply the law of large numbers so that (6) also gives the fraction of goods region $n$ buys from $i$.

Second, given the distribution of prices of actually purchased goods in region $n$, equation (5), it follows that the share of region $n$ 's expenditure on goods produced in region equals the fraction of goods bought from that region, given by (6):

$$
\frac{X_{n i}}{X_{n}}=\pi_{n i}=\frac{T_{i}\left(c_{i} d_{n i}\right)^{-\theta}}{\sum_{k=1}^{N} T_{k}\left(c_{k} d_{n k}\right)^{-\theta}}
$$

where $X_{n i}$ is region $n$ 's expenditure on region $i$ 's goods and $X_{n}=\sum_{i=1}^{N} X_{n i}$ is region $n$ 's total expenditure. Thus, the share of expenditure on region $i$-produced goods depends on how good is region $i$ 's technology, $T_{i}$, adjusted for input costs $c_{i}$ and location relative to $n\left(d_{n i}\right)$, in comparison to factor-cost and geographyadjusted technologies of all regions.

We assume that goods can be purchased by consumers or by firms as intermediate 
inputs. Production takes place by combining labor and intermediate inputs, with labor's share in production given by $\beta, 0<\beta<1$ :

$$
c_{i}=w_{i}^{\beta} p_{i}^{1-\beta}
$$

where $w_{i}$ is the wage in region $i$ and $p_{i}$ is region $i$ 's price index. Two sets of relations are central to solving for the model's equilibrium. First, substituting (8) into the expression for $\Phi$ shows that the price index in region $n$ is related to the price indices well as technology and comparative advantage parameters in all regions:

$$
p_{n}=\gamma\left[\sum_{i=1}^{N} T_{i}\left(w_{i}^{\beta} p_{i}^{1-\beta} d_{n i}\right)^{-\theta}\right]
$$

Furthermore, trade shares can be expressed as a function of wages, prices, and the parameters of the model:

$$
\frac{X_{n i}}{X_{n}}=\pi_{n i}=T_{i}\left(\frac{\gamma d_{n i} w_{i}^{\beta} p_{i}^{1-\beta}}{p_{n}}\right)^{-\theta}
$$

The model is closed by labor-market and goods-market clearing conditions which are not shown here to conserve space. Regarding labor market equilibrium, we assume in the baseline case that workers are immobile between the sector producing manufacturing goods that we have modeled so far and another sector producing non-manufacturing goods. ${ }^{13}$ Because around the year 1900 in China many workers were employed in manufacturing and other activities one might think that it is more reasonable to assume that workers can move between the manufacturing and non-manufacturing sector, and below we consider this case as well. Our measure of welfare is real GDP, given by aggregate final expenditure deflated by the region's price index.

\footnotetext{
${ }^{13}$ We use the term manufacturing for brevity; as will become clear below it also includes other goods.
} 
In the following section we describe the data, followed by the estimation of the parameters of the model.

\section{Data}

For the most part our analysis focuses on the cross section of China's internal trade in the year 1904. This year is chosen because it is the last year in which the CMC publications give aggregate bilateral trade across ports. ${ }^{14}$ This section summarizes the data that will be employed, with more details given in the Appendix. The analysis includes fifteen of China's foreign treaty ports, which are listed in Table 1 according to the ports' names as recorded by the British CMC service as well as the English transliteration of the port name (in Pinyin), and the 20th century provincial jurisdiction. The port of Guangzhou in Guangdong province, for example, is called Canton in the CMC publications. These treaty ports are defined on the basis of the customs district of each port, which includes not only the port but also the surrounding area. One might therefore prefer to think of the treaty ports as regions; we will use the terms ports and regions interchangeably. Our choice of these 15 ports is based on their importance for China's domestic trade. The three largest ports during the 19th century were Shanghai, Wuhan (Hankow), and Tianjin (Tientsin).

Figure 4 shows the locations of the fifteen ports. The figure shows that we cover broad regions of China, mainly along its coast but also along the Yangzi river. The distance between Canton (Guangzhou) and Newchwang (Niuzhuang), which are located in Guangdong and Liaoning province, respectively, is about 2,700 kilometers.

The CMC statistics include only the trade that went through the Chinese Maritime Customs Service. Although our analysis excludes land-based trade, the

\footnotetext{
${ }^{14}$ Below we will also discuss results from employing data for the years 1899 (the first year for which we have data for the same fifteen ports) and 1879 (for fourteen of the fifteen ports) as alternatives to the 1904 cross section. Furthermore, some of our analysis is based on bilateral trade data for 1895-99, see Appendix C.
} 


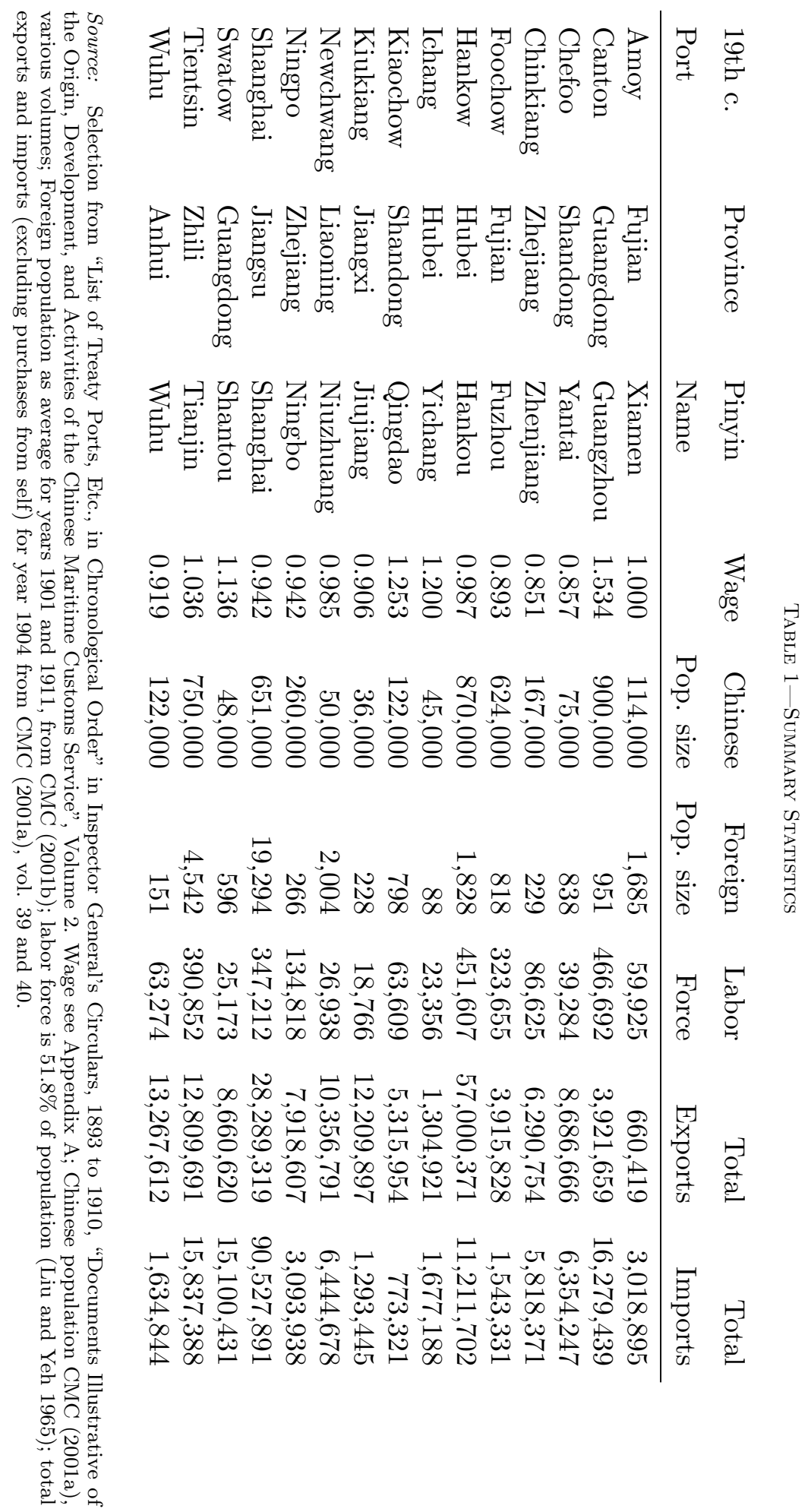




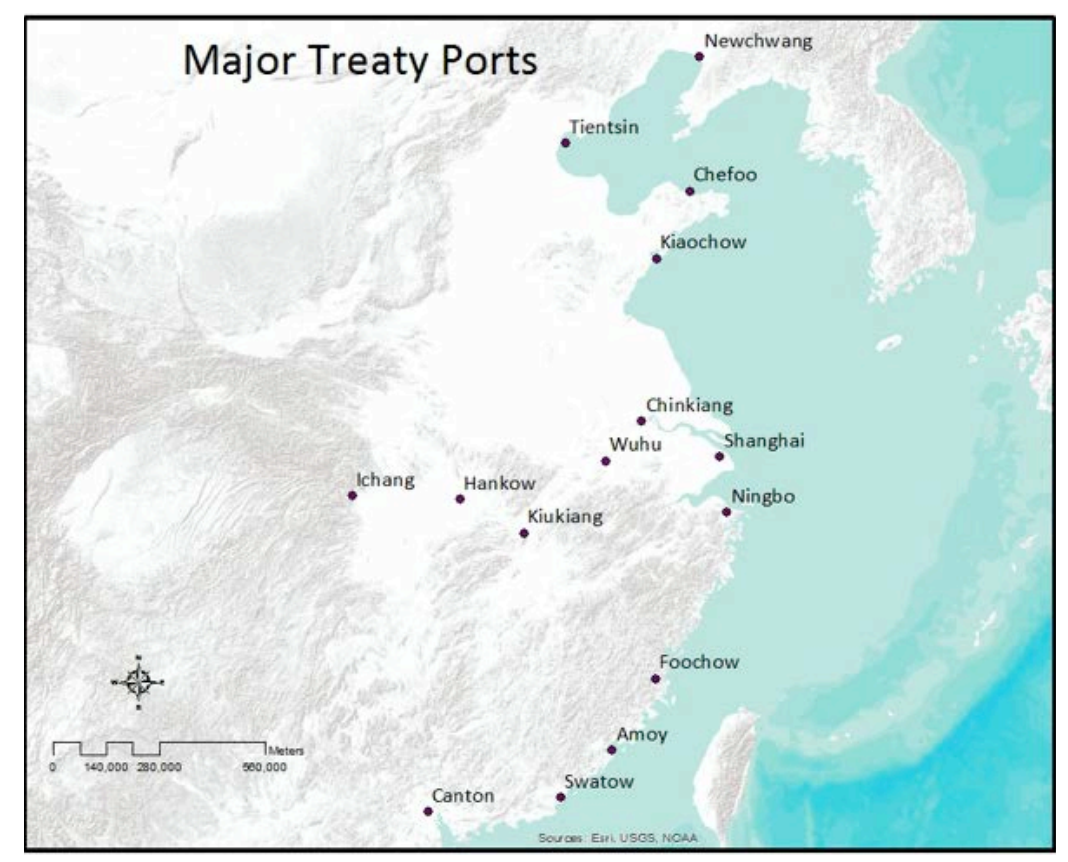

Figure 4. The 15 Treaty Ports in the Analysis.

Source: Authors' map.

amount of other water-borne trade in China (covered by the native customs system) was small in comparison to the CMC portion. One measure of the fraction of trade that is covered in the CMC statistics is that during the years 1904 to 1907, the maritime customs revenue collected at the treaty ports was about ten times as large as the native customs revenue collected outside of the CMC system (CMC 2001a, Vol. 45, pages 8-9). While land-based trade was significant, especially over short-distances, there is no reason to believe that the omission of land-based trade creates a bias in our analysis. ${ }^{15}$

\footnotetext{
${ }^{15}$ In addition to both maritime and native customs there was waterway transport that avoided all trade taxes, on which there is generally little evidence. However, this trade would have been mostly on junks, which were relatively small. For example, even though in 1904 there were five times as many Chinese-owned junks that entered the maritime customs than Chinese-owned steamers, the aggregate tonnage of these junks was only half as large as that of the Chinese-owned steamers (CMC 2001a, Vol. 45, p.23). Moreover, the trade outside the maritime customs system was mostly short-distance, whereas our analysis is primarily concerned with trade over larger distances. The importance of railroads in China around the year 1900 was still limited.
} 


\section{A. Trade data}

Two types of trade data are employed in the analysis: first, commodity-level multilateral trade at each of the fifteen regions, and second, the aggregate bilateral trade between the regions. Our analysis focuses on imports and exports of Chinese products, referred to in the Maritime statistics as "native goods". The commodity-level trade data is employed to estimate local prices, defined as the unit value of a range of goods at each port. The price difference for a given good between two regions provides an upper bound for the trade costs between these two regions. Before we turn to that, the following discusses aggregate bilateral trade of our regions.

Figure 5 shows the matrix of bilateral trade, with the thickness of each line proportional to the size of the flow. Exports are shown in the same color shade as the region's label and are offset towards the center of the figure. Hankow exports a large amount of its production to Shanghai, for example, while Tientsin's imports from Hankow are smaller than Tientsin's imports from Shanghai.

Importantly, the trade volumes shown in Figure 5 are locally produced in each of the fifteen regions. The Maritime Trade statistics are exceptional in that they provide information on re-export trade separately from local-origin trade. Shanghai, in particular, re-exports goods from other Chinese regions to an extent that exceeds its exports of local origin. ${ }^{16}$ If each region would export to every other region, Figure 5 would show $15 \times 14$ trade flows; however, $22 \%$ of the bilateral flows are equal to zero. ${ }^{17}$ Also note that this trade is not balanced in the year 1904; we do not examine issues of inter-temporal trade in our analysis.

Our discussion of aggregate trade data is not complete without covering the trade of region $i$ with itself. Because we do not have information on production in region

\footnotetext{
${ }^{16}$ Note that if lower trade costs or technology improvements would lead to higher re-exports this might be associated with welfare gains in addition to those resulting from locally produced goods. In that sense, the welfare gains in the model below, which does not include re-exports, should be thought of as a lower bound.

${ }^{17}$ In the estimation we add one before taking logs; using Poisson-type regression models does not change our main results.
} 


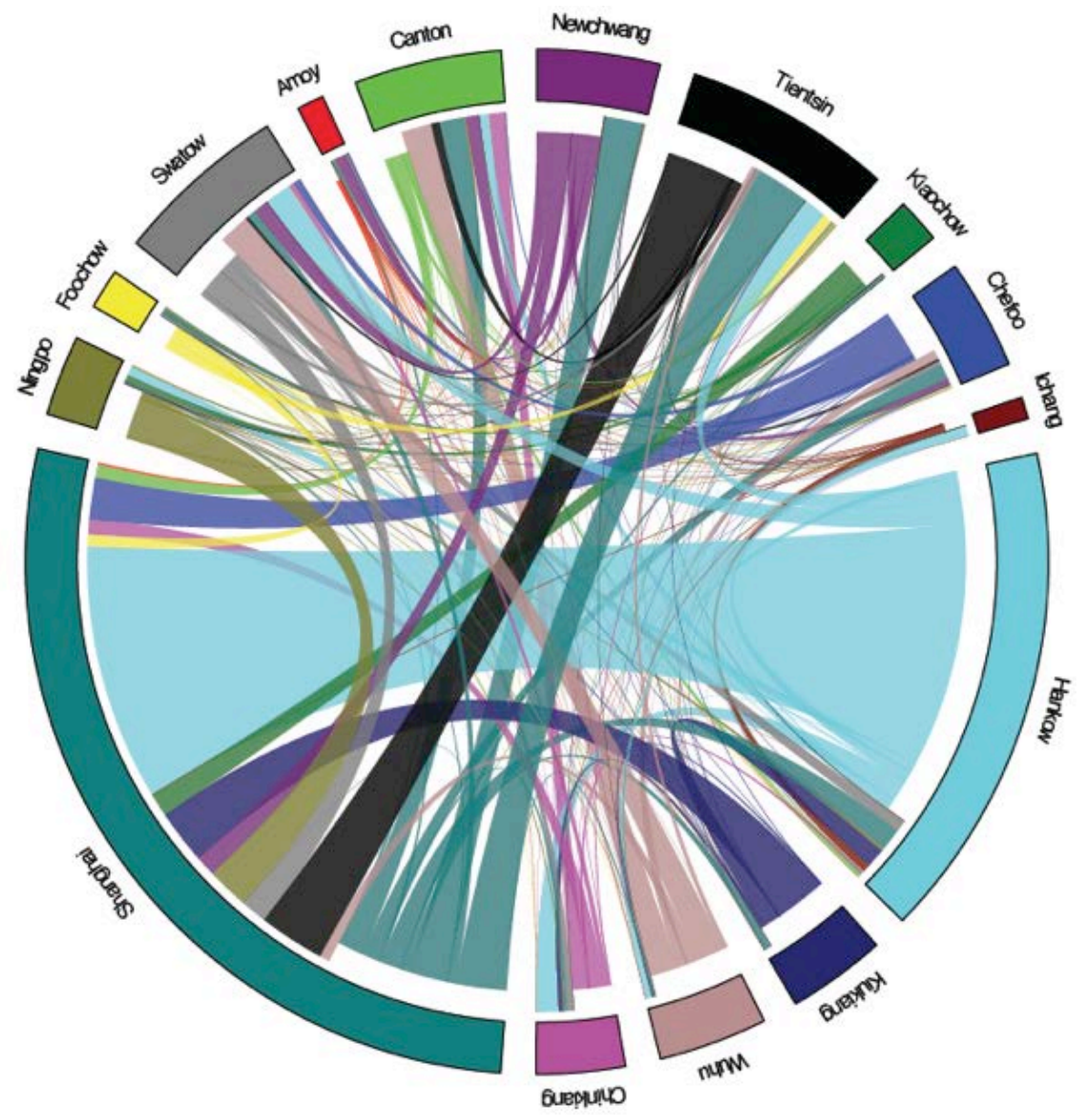

Figure 5. Bilateral Trade Between Regions

Source: Calculated from CMC trade data.

$i$, we cannot follow the usual approach of obtaining region $i$ 's purchases from itself as its production minus total exports. Instead, we first run a gravity equation using all bilateral data on trade between regions $i$ and $j$. With the coefficient on distance in hand, the purchase of region $i$ from itself could be estimated by the predicted value of trade given a zero value of distance. Following the empirical gravity literature, however, we modify this approach to account for the size of region $i$ (which is not zero) as its internal distance (see Appendix C).

Turning to the commodity-level trade data, Figure 6 provides some detail on the 
most important commodities in four regions, as well as a comparison between the size of domestic and foreign trade at the commodity level. With the exception of Silk Piece goods out of Canton and Raw Cotton from Shanghai, domestic trade is larger than foreign trade. Furthermore, foreign trade exceeds domestic trade in ports other than Shanghai.
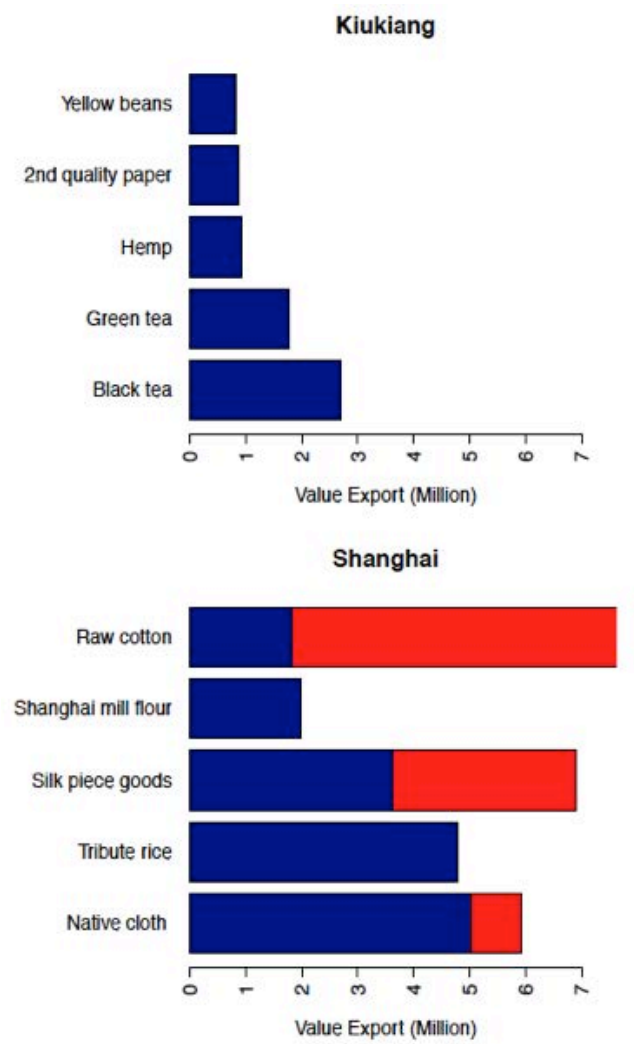
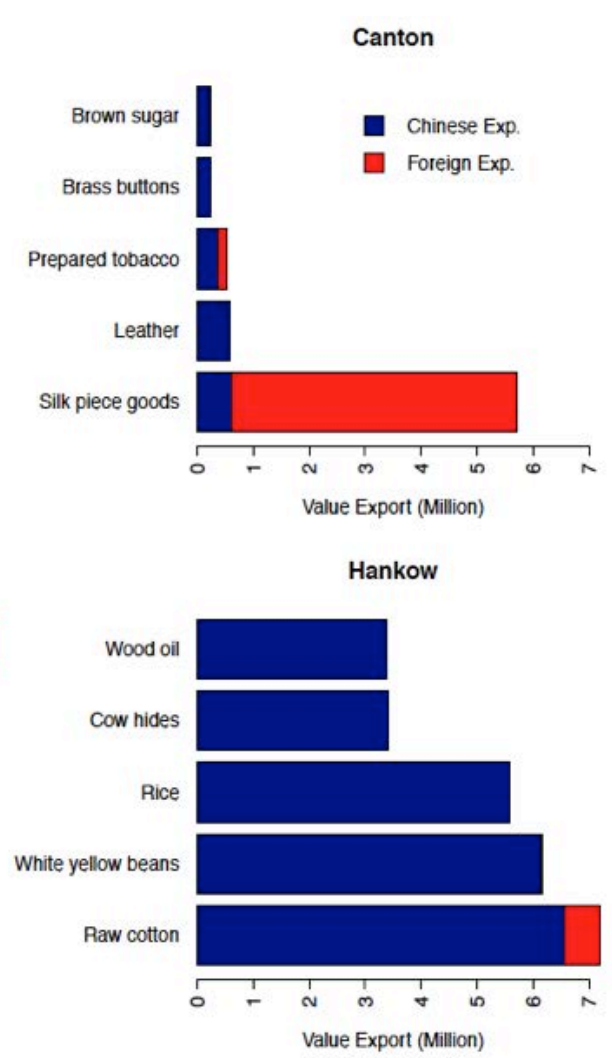

Figure 6. Five Key Commodities, By Region

Source: Chinese Maritime Customs CMC (2001a).

The commodity-level trade data is employed to estimate the key parameter $\theta$ from examining price differences across ports. For this purpose we pick 26 commodities that are traded between virtually all fifteen regions. These commodities include coal, matches, as well as cotton goods and cotton yearn. Table B in the Appendix gives details on these commodities. In Table 2, we show the average 
price difference in each region versus all other regions. With the exception of Table 2-Bilateral Price Differences on 26 Commodities

\begin{tabular}{lclc} 
Region & Avg. Percent Difference & Region & Avg. Percent Difference \\
\hline Amoy & 2.4 & Kiukiang & 8.7 \\
Canton & -0.2 & Newchwang & 0.1 \\
Chefoo & -0.4 & Ningpo & 1.9 \\
Chinkiang & -1.3 & Shanghai & 1.4 \\
Foochow & -1.6 & Swatow & 9.9 \\
Hankow & -0.1 & Tientsin & 24.5 \\
Ichang & 1.3 & Wuhu & -0.5 \\
Kiaochow & -4.3 & & \\
Source: Chinese Maritime Customs CMC (2001a). &
\end{tabular}

Tianjin, the average price differences are not far from zero. This is consistent with the hypothesis that for most regions, there are both low-cost and high-cost products.

\section{B. Wages}

We obtain information on wages in the treaty ports from the Chinese Maritime Customs' Decennial Reports, CMC (2001b). These sources cover our fifteen regions over years 1892 to 1921; the director of the customs station in each port was asked to report typical wages for particular occupations paid in his district. Occupations include both more and less skilled jobs such as painters, coolies, silk weavers, and manual laborers. The most frequent records are available for carpenters. On average, according to these data workers are paid about 390 copper cash for a day's of work. This figure is relatively close to the figure of 422 copper cash wage for a day's work in the year 1900 cited in Allen et al. ((2009, Appendix Table 1). Given the relatively small number of 294 wage observations, we have estimated a region's wage from a hedonic regression across all ports (including occupation and year fixed effects). This is discussed further in Appendix A. Average wages across China's treaty ports varied to some degree across treaty ports; 
the lowest wage $w_{i}$ is obtained for Chinkiang at 0.85 , the highest for Canton at 1.5. We have examined the robustness of our findings using alternative regional wages estimated from a subset of the Decennial Reports wage data together with predictions from a polynomial in longitude and latitude, finding similar results.

\section{Labor Force and Gross Product}

We estimate the labor force in each region, $L_{i}$, by applying estimates of the labor force participation in China from Liu and Yeh (1959) to figures on the Chinese and foreign population living in each region, from CMC (2001a,b). Our GDP estimates are equal to the wage bill in each region, estimated as $w_{i} L_{i}$, plus the contribution from land, which is estimated based on Perkins (1969). See Appendix B for details. ${ }^{18}$

\section{Parameter Estimation}

In this section, we present the empirical strategy used to estimate the parameters of the model. In the first step, we estimate the value of the comparative advantage parameter, $\theta$. Then, given the latter, we estimate the parameters that capture each region's state of technology, $T_{i}$, and bilateral geographic barriers, $d_{n i}$.

\section{A. Comparative Advantage}

The model described above provides a simple way of estimating the comparative advantage parameter, $\theta$. Dividing equation (7) by the equivalent expression for destination region $i$, using the price indices and taking logarithms, one can show that:

$$
\ln \left(\frac{X_{n i} / X_{n}}{X_{i i} / X_{i}}\right)=-\theta \ln \left(\frac{p_{i} d_{n i}}{p_{n}}\right)
$$

\footnotetext{
${ }^{18}$ We employ Perkins' (1969) estimates of the value of provincial agricultural production across thirteen products, and use data on the fraction of people living in each region i relative to total provincial population to apportion a fraction of provincial land income to each region.
} 
We use data on aggregate bilateral trade flows and relative prices for each region pair to recover a simple method-of-moments estimate of $\theta$. The left-hand side of (11) is the (log of) the share of region n's expenditure on region $i$ 's goods (normalized by region $i$ 's share). ${ }^{19}$

The bilateral trade flows data provide a measure of that dependent variable.

The right-hand-side of (11) requires more discussion. The logarithmic term, which is not directly observable, depends on the relative price indices of regions $n$ and $i$, and the size of geographic barriers between the two regions, $d_{n i}$. We construct a proxy for that term, $D_{n i}$, based on the prices of individual commodities in each port mentioned above:

$$
D_{n i}=\max _{j}\left\{r_{n i}(j)\right\}-\sum_{j=1}^{J} \frac{r_{n i}(j)}{J}
$$

where $\max 2_{j}$ indicates the second highest value across all $J$ commodities and $r_{n i} \equiv \ln p_{n}(j)-\ln p_{i}(j)$. The intuition behind the first term comes from the model: a buyer from region $n$ can always purchase any good $j$ from region $i$ at the effective price $p_{i}(j) d_{n i}$. Thus, $p_{n}(j)$ cannot be higher than that effective price, making $d_{n i}$ the upper bound $(\max )$ of the relative price between regions $n$ and $i$. The second term in (12) captures the relative price indices part in (11). We use the second highest value across all goods to avoid the potential bias from measurement error for the prices of certain commodities.

Using the proxy given in (12), the method-of-moments estimation procedure yields a value of the comparative advantage parameter of $\theta=18.7 .^{20}$ This estimate is higher than the preferred estimate of 8.28 of Eaton and Kortum (2002) for OECD countries in 1990, from a range of estimates between 3.60 and 12.86. Alternatively, one can add an error to (11) and estimate $\theta$ with data on prices and distance in an

\footnotetext{
${ }^{19}$ We only use region pairs where $n \neq i$. For the case $n=i$, equation (11) is an identity. With data on 15 regions, we end up with a total of 210 observations.

${ }^{20}$ We have examined how this estimate varies given our set of commodities, finding that it is quite robust to dropping individual items from our list of 26 commodities.
} 
OLS regression; using this approach we obtain $\theta=13.9 .{ }^{21}$ Overall this suggests that China's regional diversity in productivity across goods around the year 1900 was relatively small compared to other settings. This will be important for our analysis of welfare gains from trade.

\section{B. Technology and Geography Parameters}

Armed with an estimate of the comparative advantage parameter $\theta$, we proceed to estimate the remaining parameters of the model, namely the parameters that capture regional technology, $T_{i}$, and geographic barriers, $d_{n i}$. As in Eaton and Kortum (2002), the model implies that

$$
\ln \frac{X_{n i}^{\prime}}{X_{n n}^{\prime}}=S_{i}-S_{n}-\theta \ln d_{n i}
$$

where

$$
\ln X_{n i}^{\prime} \equiv \ln X_{n i}-[(1-\beta) / \beta] \ln \left(X_{i} / X_{i i}\right)
$$

and

$$
S_{i} \equiv \frac{1}{\beta} \ln T_{i}-\theta \ln w_{i}
$$

Equation (15) provides a measure of a region's competitiveness, $S_{i}$, defined as its technology adjusted for labor costs. As for the geographic barriers in (13), they are modeled as follows:

$$
\ln d_{n i}=\sum_{b=1}^{6} d_{b} D I S T_{b}+m_{n}+\delta_{n i}^{1}+\delta_{n i}^{2}
$$

where $D I S T_{b}$ takes the value 1 if the distance between regions $n$ and $i$ lies in

\footnotetext{
${ }^{21}$ Eaton and Kortum consider the estimate based on (11) as their preferred estimate; in our case, this is $\theta=18.7$. For comparison, Donaldson (2015) estimates $\theta=5.2$ across 85 commodities in colonial India.
} 
the interval $b=1, \ldots 6$, and takes the value zero otherwise, and $m_{n}$ captures destination effects. ${ }^{22}$ The last two terms in (16) capture all other unobserved geographic barriers between regions $n$ and $i$ affecting one-way $\left(\delta_{n i}^{1}\right)$ and two-way $\left(\delta_{n i}^{2}\right)$ trade.

Combining (13) and (16) yields:

$$
\ln \frac{X_{n i}^{\prime}}{X_{n n}^{\prime}}=S_{i}-S_{n}-\theta m_{n}-\sum_{b=1}^{6} \theta d_{b} D I S T_{b}-\theta \delta_{n i}^{1}-\theta \delta_{n i}^{2}
$$

Adding a regression error, equation (17) is our estimation equation. The dependent variable is based on aggregate bilateral trade data between the ports, and we assume that $\beta$, the cost share of labor, is 0.36. From equation (17), the competitiveness measures are estimated as region-specific dummies. The one-way and two-way unobserved barriers introduce heteroskedasticity and correlation between the errors of different region-pair observations (i.e., the error terms of the equations for the pairs $(n, i)$ and $(i, n)$ have non-zero correlation). Thus, we estimate this regression by generalized least squares.

Note that the coefficients on the distance bins and destination effects are not separately identified from the comparative advantage parameter, $\theta$. However, given our estimate of the latter from above, we can identify those coefficients to obtain the geographic barriers parameters, $d_{n i}$. Finally, with data on wages and the estimated values of each region's competitiveness, $S_{i}$, we use (15) to recover the technology parameters, $T_{i}$.

Table 3 presents the estimation results for the competitiveness measure and the implied values of the technology parameters. The table shows that Shanghai is the most competitive of the 15 regions, with the second highest state of technology, only surpassed by Swatow that, due to its relatively higher wages, loses part of

\footnotetext{
${ }^{22}$ The distance intervals (in miles) we use are as follows: [0,200); [200,400); [400,600), [600,800); $[800,1000) ;[1000$, maximum]. We also explore other specifications with polynomials of the log of distance instead of the distance dummies, finding similar results.
} 
its competitiveness. The result that Shanghai is highly competitive conforms well with its export level, which is twice that of Tianjin even though the two ports are roughly equal in size (see Table 1). Also interesting is the case of Canton (Guangzhou); while the port is third in terms of technology, it ranks 10th in terms of competitiveness due to the high wages in that region.

Table 3-Technology and Competitiveness Results

\begin{tabular}{lrr} 
& Competitiveness & Technology \\
\hline Shanghai & $7.38^{* * *}$ & 1.00 \\
Swatow & $5.98^{* * *}$ & 2.13 \\
Chefoo & $3.64^{* *}$ & 0.14 \\
Ningbo & $3.20^{*}$ & 0.22 \\
Newchwang & 2.59 & 0.24 \\
Hankow & 2.37 & 0.23 \\
Tientsin & 1.92 & 0.27 \\
Amoy & -0.55 & 0.09 \\
Kiaochow & -0.79 & 0.36 \\
Canton & -2.02 & 0.90 \\
Foochow & -2.33 & 0.02 \\
Wuhu & $-2.97^{*}$ & 0.02 \\
Chinkiang & $-3.67^{* *}$ & 0.01 \\
Kiukiang & $-7.21^{* * *}$ & 0.00 \\
Ichang & $-7.54^{* * *}$ & 0.02
\end{tabular}

Note: Ports ordered in terms of their estimated competitiveness. Statistical significance at $1 \%, 5 \%$, and $10 \%$ indicated by $* * *, * *$, or $*$, respectively. The technology parameters are computed using wages and the estimated competitiveness measures, by solving for $T_{i}$ in (15) and using $\theta=18.7$.

Source: Authors' calculations.

Table 4 presents the estimation results for the distance and destination dummies in (17), as well as the implied percentage effect of each particular barrier on costs. As can be seen in the table, costs increase with distance, although not in a monotonic way. In the lower part of the table, we see that exporting to Shanghai costs $48 \%$ less than exporting to the average region, while exporting to Ichang increases costs by $112 \%$ relative to the average region.

With these parameter estimates in hand, we are now ready to perform a number of counterfactual analyses. 
TABle 4-Geographic BarRiers

\begin{tabular}{ccc} 
Distance & Geography parameters & Percentage effect on cost \\
\hline$[0,200)$ & -2.76 & 15.9 \\
{$[200,400)$} & $-3.84^{* * *}$ & 22.8 \\
{$[400,600)$} & $-7.04^{* * *}$ & 45.71 \\
{$[600,800)$} & $-7.75^{* * *}$ & 51.35 \\
{$[800,1000)$} & $-6.94^{* * *}$ & 44.94 \\
{$[1000$, maximum $]$} & $-5.69^{* * *}$ & 35.56 \\
\hline
\end{tabular}

DESTINATION

Amoy

Canton

Chefoo

Chinkiang

Foochow

Hankow

Ichang

Kiaochow

Kiukiang

Newchang

Ningbo

Swatow

Tientsin

Wuhu

Shanghai

$-3.38$

$-0.69$

3.66

$-3.00$

$-1.54$

$7.59^{* * *}$

$-14.05^{* * *}$

$-4.6^{*}$

$-4.54^{*}$

$-0.69$

4.21

3.91

3.58

$-2.82$

$12.35^{* * *}$
19.81

3.76

$-17.78$

17.40

8.58

$-33.36$

111.98

27.89

27.48

3.76

$-20.16$

$-18.87$

$-17.42$

16.28

$-48.34$

Note: Estimated parameters for distance dummies and destination effects from equation (17). The latter are normalized so that the sum of all destination effects is equal to zero. Statistical significance at $1 \%$, $5 \%$, and $10 \%$ indicated by $* * *, * *$, or $*$, respectively. The implied percentage effect on cost for each parameter $\mathrm{d}$ is calculated as $100 \mathrm{x} \exp (\mathrm{d} / \vartheta-1)$, using $\theta=18.7$.

\section{Counterfactuals}

In this section, we simulate counterfactuals involving changes in some of the model parameters. In particular, we explore the welfare effects of: 1) increases in the state of technology of specific ports; and 2) lower trade costs across the board. In all cases, our measure of welfare is real GDP.

Table 5 presents the results from changes in the state of technology of specific ports, $T_{i}$. We start with an increase of $20 \%$ in the state of technology of the biggest port, Shanghai, holding everything else in the model constant. An increase of $20 \%$ 
Table 5-Port-Specific Technology and Welfare

\begin{tabular}{|c|c|c||c|c|}
\hline & \multicolumn{2}{|c||}{ Technology Shanghai up 20\% } & \multicolumn{2}{c|}{ Technology Hankow up 20\% } \\
\cline { 2 - 5 } & Welfare \% $\%$ & $\%$ /Shanghai & Welfare $\% \Delta$ & $\%$ /Hankow \\
\hline Amoy & 0.07 & 4.64 & 0.06 & 3.94 \\
Canton & -0.01 & -0.44 & -0.01 & -1.03 \\
Chefoo & 0.15 & 10.19 & 0.13 & 8.86 \\
Chinkiang & 0.27 & 18.19 & 0.10 & 7.08 \\
Foochow & -0.03 & -2.25 & -0.03 & -1.97 \\
Hankow & 0.05 & 3.41 & 1.45 & 100 \\
Ichang & 0.16 & 10.78 & 0.16 & 10.87 \\
Kiaochow & 0.12 & 8.09 & 0.06 & 3.89 \\
Kiukiang & 0.20 & 13.55 & 0.21 & 14.49 \\
Newchwang & 0.11 & 7.59 & 0.10 & 6.60 \\
Ningbo & 0.50 & 33.78 & -0.23 & -16.11 \\
Swatow & 0.19 & 12.62 & 0.18 & 12.35 \\
Tientsin & -0.07 & -4.44 & 0.01 & 0.68 \\
Wuhu & 0.21 & 14.42 & 0.13 & 9.15 \\
Shanghai & 1.47 & 100 & -0.01 & -0.96 \\
\hline Average & 0.226 & \multicolumn{4}{|c}{} \\
\hline
\end{tabular}

Note: Shown are the welfare effects of increasing either Shanghai's (first half) of Hankow's (second half) technology parameter $\left(T_{i}\right)$ by $20 \%$. Columns 2 and 4 show the percentage change in welfare relative to the baseline (where technology parameters are those given in Table 3). Columns 3 and 5 show the same welfare changes relative to the welfare gain in the port whose technology parameter increases.

is reasonable given that the operation of customs by the CMC brought with it a wide range of improvements, such as dredging of the harbor, new lighthouses, increased protection from pirates, and the customs process itself. The first column reports the percentage change in welfare at each port derived from this increase in Shanghai's technology. The second column normalizes Shanghai's welfare change to 100. The improvement in Shanghai's productivity leads to a welfare change in this region of about $1.5 \%$. Importantly, the welfare gains are not confined to this port. Because of domestic trade, other ports in the vicinity of Shanghai, such as Ningbo, Chinkiang, and Wuhu also experience significant welfare gains. Even Swatow, at 1,300 km from Shanghai, experiences around 13\% of the welfare increase of Shanghai. Also noteworthy is the fact that not all regions benefit from Shanghai's technology improvement. Because factor costs, income, and 
production patterns respond endogenously to this change, welfare actually falls in some ports like the distant Tientsin.

The last two columns present the results of a similar experiment with Hankow's technology. The welfare gains in Hankow are similar to those for Shanghai in the previous experiment. Welfare gains spread to other regions, especially the ones close to Hankow, but with lower magnitudes than in the case of Shanghai's productivity improvement. This is evident by comparing Figures 7 and 8 .

Figure 7. Welfare Effects of Higher Technology in Shanghai

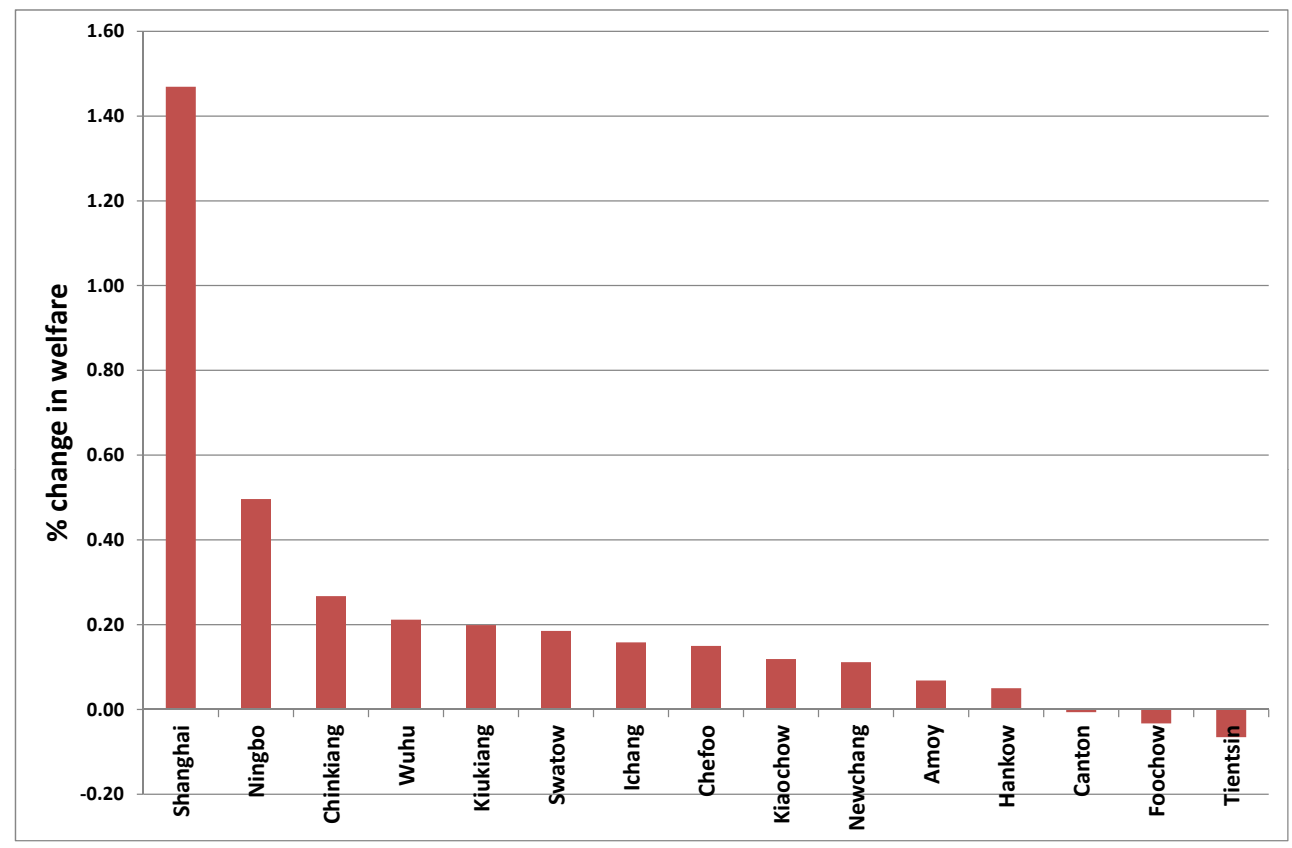

In Table 6, we present the results of two experiments involving changes in trade costs across the board, where we keep all regions' technology parameters fixed. We start by lowering trade impediments to half of the original levels underlying Table 4. This is a drastic reduction of trade barriers which, however, could be plausible given the introduction of steam ships during the late 19th century. We see that trade increases by $13 \%$ as a result of the lower barriers. Welfare gains, however, are unevenly distributed across ports, and some regions, in particular 
Figure 8. Welfare Effects of Higher Technology in Hankow

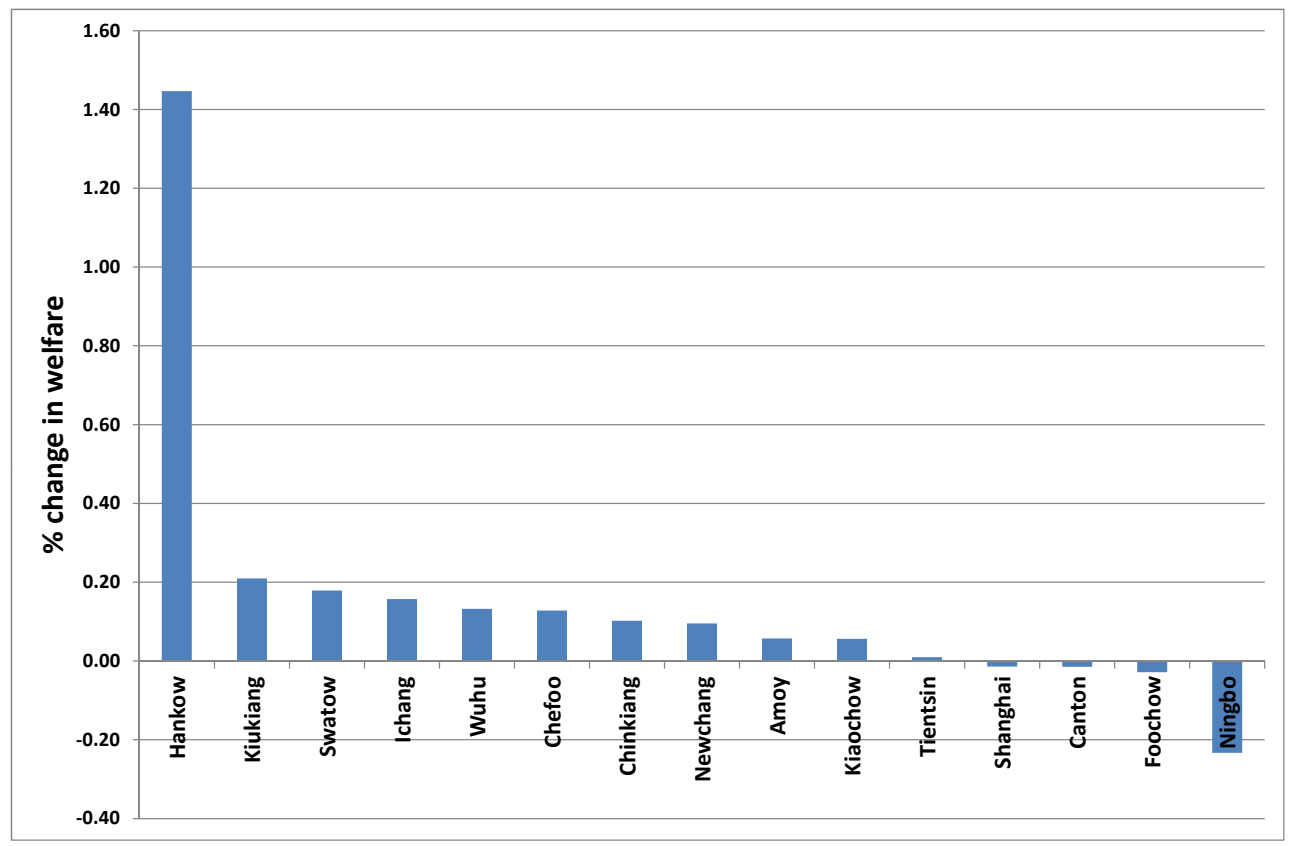

Shanghai and Ningbo, experience welfare losses.

The reason for this lies in the reallocation of production and trade. The intuition is that lower trade barriers across the board diminish the advantage that Shanghai has based on its technology. More generally, notice that the four regions with the lowest welfare gains due to lower trade barriers are Shanghai, Ningbo, Chefoo, and Swatow, which are the four regions with the highest level of labor-cost adjusted technology (or competitiveness, see Table 3). For all competitive exporters, lower trade barriers means that they might not be any longer the low-cost source of supply for some importing regions, relative to slightly less competitive regions that are located geographically closer. If a competitive exporter ceases to serve a particular region, this is a movement in the direction of autarky, and welfare falls.

The difference between the more strongly negative welfare effects in Shanghai and Ningbo, compared to Swatow and Chefoo, turns on their geographic loca- 
tion. Shanghai and Ningbo are centrally located close to the Yangzi Delta. This means that before the reduction of trade barriers, given their high level of competitiveness they exported to many other locations, and the reduction in trade barriers has the potential that they lose their status of low-cost supplier in several importing regions. In contrast, Chefoo and Swatow are located in geographically more remote parts of China, North and South, respectively. They lose some markets as the result of the lower trade barriers, but they hold on to others due to their geographic remoteness. As a consequence, Chefoo and Swatow lose less than Shanghai and Ningbo. Generally, we find that geography, rather than wage differences play the major role in determining the distribution of welfare effects from trade cost reductions. This can be seen from computing the welfare effects of a $50 \%$ trade cost reduction under the assumption that wages across ports are equal. It turns out that this leads to almost the same welfare effects of the trade cost reduction as with wages differing across ports (correlation greater than 0.99).

In the second half of Table 6 we experiment with a more extreme reduction in geographic barriers from the baseline to zero-gravity (setting all trade cost coefficients to virtually $d_{n i}=1$ ). As a result, overall trade increases more than in the previous case, although the increase remains with $54 \%$ relatively modest. The distribution of welfare gains gives the same pattern as before.

The welfare gains arise with lower trade costs because most regions spend more of their total expenditure on imports, rather than their own production. Indeed, one can show that given $\theta$, the share a region imports is a sufficient statistic for the welfare effect of a change in trade costs: if the import share goes up, welfare rises, and vice versa (see Costinot and Rodriguez-Clare 2013). The change in a region's import share as the result of lower trade costs is shown in Figure 9 for all fifteen regions. On average, the import share goes up by twenty-six percentage points. The largest increase is in Amoy, where the import share goes from $15 \%$ to a staggering $82 \%$, or sixty-seven percentage points. In contrast, the import share falls by nine percentage points in Shanghai, and this move towards autarky 
Table 6-Lower Geographic Barriers and Welfare

\begin{tabular}{|c|c|c|c||ccc|}
\hline & \multicolumn{3}{|c||}{ Trade barriers down 50\% } & \multicolumn{3}{c|}{ Trade barriers down to zero } \\
& \% change relative to baseline & \% change relative to baseline \\
& Welfare & Prices & Wages & Welfare & Prices & Wages \\
\hline Amoy & 2.58 & -7.15 & -2.07 & 22.03 & -35.69 & 16.35 \\
Canton & 1.67 & -0.03 & 3.24 & 10.18 & -17.51 & 4.25 \\
Chefoo & 0.17 & 4.25 & 9.36 & 5.79 & -6.35 & 12.64 \\
Chinkiang & 0.75 & -2.90 & -3.53 & 13.68 & -27.00 & 7.91 \\
Foochow & 2.15 & 0.05 & 4.02 & 17.21 & -21.23 & 13.61 \\
Hankow & 2.01 & 10.23 & 10.30 & 2.49 & 6.95 & 8.74 \\
Ichang & 8.90 & -26.89 & -24.80 & 37.89 & -92.07 & -31.31 \\
Kiaochow & 1.95 & -6.13 & -2.79 & 19.84 & -35.08 & 11.90 \\
Kiukiang & 3.51 & -8.00 & -2.26 & 18.98 & -39.09 & 16.31 \\
Newchwang & 4.22 & -3.48 & 9.96 & 19.79 & -25.86 & 28.25 \\
Ningbo & -31.41 & 15.12 & -32.25 & -35.40 & 9.79 & -41.17 \\
Swatow & 0.27 & 3.22 & 14.44 & 5.45 & -7.19 & 17.69 \\
Tientsin & 3.43 & 4.25 & 8.95 & 10.55 & -6.54 & 12.51 \\
Wuhu & 2.38 & -4.59 & 1.77 & 15.37 & -28.89 & 13.12 \\
Shanghai & -17.29 & 23.73 & -7.76 & -32.62 & 31.00 & -22.50 \\
\hline \multicolumn{7}{|c|}{} \\
\cline { 2 - 6 } & $\%$ change in overall trade & $\%$ change in overall trade \\
\cline { 2 - 6 }
\end{tabular}

Note: The table shows the results of lowering geographic barriers by $50 \%$ (first half) or to virtually zero ( 0.001 of the baseline barriers; second half) from the baseline estimated values provided in Table 4 without changing states of technology (which are fixed at the estimated levels provided in Table 3). The comparative advantage parameter $\theta$ is fixed at 18.7 .

is the reason why welfare falls in Shanghai.

In the following we examine these findings along a number of dimensions.

Changes over time The results so far are based on trade between these regions in the year 1904. Given that China's domestic trade grew substantially since the first treaty ports were opened, it is interesting to compare our results with those for an earlier year. ${ }^{23}$ Striking a balance between obtaining a similar sample and a substantial time difference, we pick the year 1879 where we have trade data for all but one of the fifteen treaty ports in the 1904 sample (Kiaochow is not present in

\footnotetext{
${ }^{23}$ For example, locally produced exports to other Chinese regions of two of the largest treaty ports, Hankow and Shanghai, grew by $5.2 \%$ and $3.1 \%$ annually between 1879 and 1904 in, respectively (based on CMC 2001a), Vols. 8 and 39).
} 
Figure 9. Share of Expenditure Imported Indicates Welfare Effect

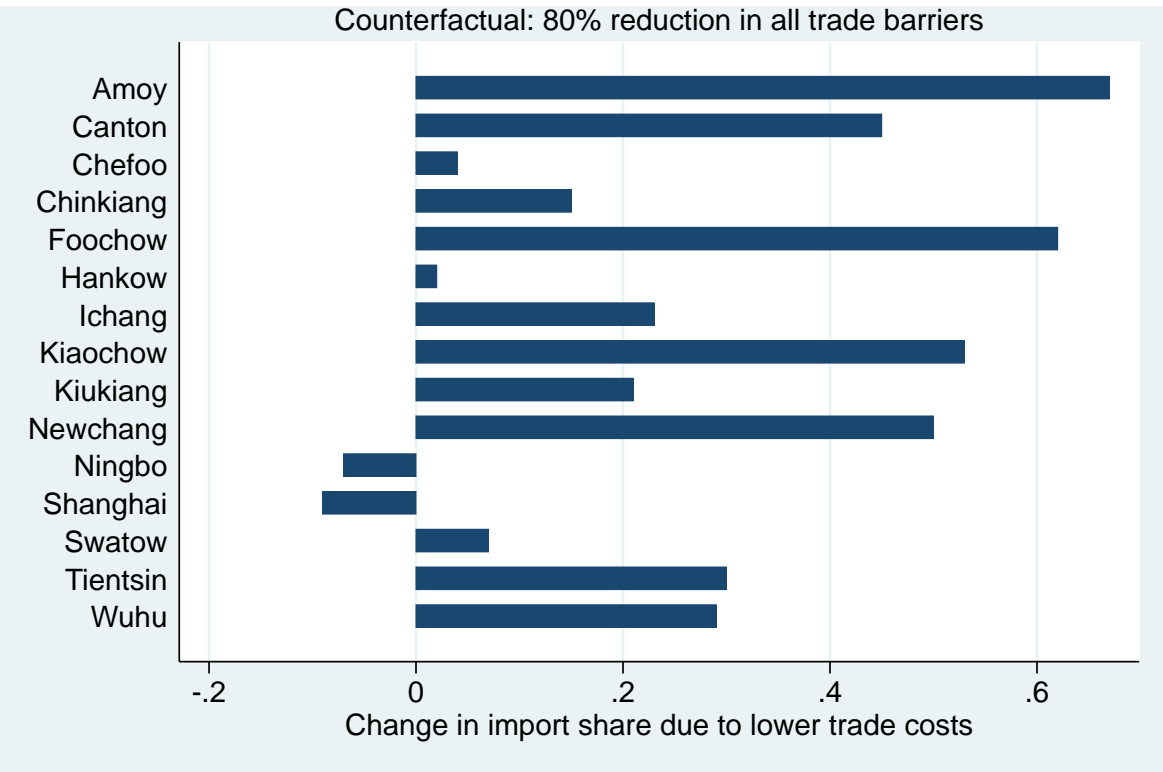

1879). Comparing the geographic barriers estimated with the 1879 versus the 1904 trade flows, Figure 10 shows that trade barriers were between 3 and 9 times higher in the earlier period. This result is consistent with the increase in trade that took place over these twenty five years. Despite this, we find that many of our 1904 results carry over to the earlier period with higher trade barriers. In particular, the welfare changes resulting from a $20 \%$ improvement in Shanghai's technology are similar based on 1879 and 1904 trade data (with a correlation of 0.86 across 14 ports). ${ }^{24}$ Employing trade data for fifteen ports from the year 1899, we find the results to be similar to 1904; for example, the correlation between the welfare changes across ports resulting from a $20 \%$ increase in Shanghai's technology is close to 0.99 for the 1899 versus 1904 trade data.

Mobile labor between sectors In our baseline estimation we assume that labor is immobile between the manufacturing and non-manufacturing sector. To assess

\footnotetext{
${ }^{24}$ We find greater differences for the trade cost reduction counterfactuals; this is due to the different baseline geographic trade barriers, as shown in Figure 10.
} 
Figure 10. Geography as a Barrier: 1879 and 1904 Compared

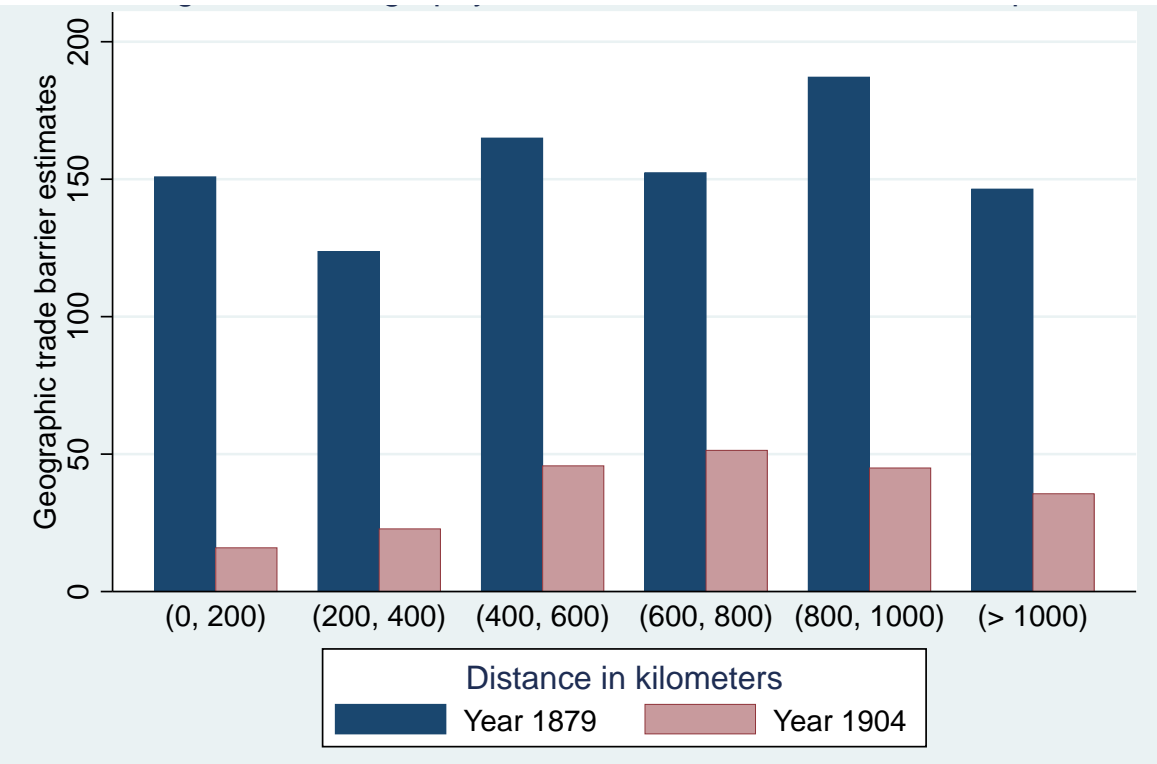

the importance of this for our results we have also considered the mobile labor case. First, a $50 \%$ reduction of all trade costs results in a $11 \%$ increase of trade, compared to $13 \%$ with immobile labor. This reduction in the trade response is due to the fact that mobile labor gives another margin of adjustment, and less needs to be achieved through trade. Aggregate welfare gains are larger with mobile labor, although the distribution of welfare gains across ports is quite similar. These results suggest that while immobile labor is the conservative assumption in terms of welfare gains from lower trade costs, it does not drive our main findings.

Wage and GDP estimation We have also examined the role of our wage and GDP estimation for the results by experimenting with a number of alternative estimates. $^{25}$ In all cases the empirical findings in the counterfactuals were very close to the baseline analysis above.

\footnotetext{
${ }^{25}$ In particular, we have added geographically interpolated wages for some missing locations. We have also increased the share of non-labor factors in GDP.
} 


\section{Concluding discussion}

In this paper we provide estimates of a general-equilibrium trade model for China in the year 1904, employing a new, commodity-level dataset for fifteen major treaty ports. We show that the welfare effects of trade depend critically on each port's productivity, China's economic geography via trade costs, and the degree of regional diversity in production. Domestic trade frictions are estimated to be substantial, far from the frictionless world that is commonly assumed. Moreover, geographic barriers loom large in shaping the welfare gains from technology improvements and trade cost reductions.

There are two main findings. First, we find that a change in productivity for any of the ports has effects throughout China. Specifically, a 20\% increase in Shanghai's productivity raises welfare in Shanghai by about 1.5\%; because of trade, however, welfare increases not only in Shanghai but also in other regions. For example, the welfare increase at a 1,300 kilometers distance away from Shanghai, in Swatow, is still $13 \%$ of the welfare increase due to the improvement in technology in Shanghai. Since trade diminishes smoothly over geographic space, whether between two treaty ports or between treaty port and hinterland, these results suggest that technology improvements or trade cost reductions in treaty ports may have had a positive welfare effect on large portions of China. Furthermore, because factor costs, income, and production patterns respond endogenously, welfare in some ports can actually fall, as it does in the relatively distant Tianjin. The endogenous reallocations of production and trade also explain the negative welfare effects we find for some ports like Shanghai and Ningbo when trade impediments are reduced across the board.

Second, we find evidence of relatively small regional diversity in productivity across goods for China during the Treaty Port Era, at least in comparison with that found in high-income countries of the late 20th century. Since differences in productivity across goods - comparative advantage - is the source of the gains 
from trade in our framework, this provides a rationale for the aggregate size of welfare gains from internal trade we find for China in this historical period. 


\section{REFERENCES}

[1] Allen, R., J. Bassino, D. Ma, C. Moll-Murata, and J.L. van Zanden (2005), "Wages, Prices, and Living Standards in China, Japan, and Europe, 1738$1925 "$, June 2005.

[2] Brandt, L., D. Ma., and T. G. Rawski (2014), "From Divergence to Convergence: Reevaluating the History behind China's Economic Boom." Journal of Economic Literature, 52(1): 45-123.

[3] Broadberry, S., H. Guan, and D. Li (2014), "China, Europe, and the Great Divergence: A Study in Historical National Accounting, 980-1850", London School of Economics working paper, July.

[4] Cassel, P. K. (2012), Grounds of Judgment. Extraterritoriality and Imperial Power in Nineteenth-Century China and Japan, Oxford University Press.

[5] Chang, J. (1969), Industrial Development in Pre-Communist China: A Quantitative Analysis. Chicago: Aldine.

[6] CMC (2001a), Returns of Trade and Trade Reports, China, Imperial Maritime Customs, (The Maritime Customs after 1910), Statistical Department of the Inspectorate General of Customs, Shanghai, various years.

[7] CMC (2001b), Decennial Reports, China, Imperial Maritime Customs, (The Maritime Customs after 1910), Vol. 1 (1882-1891), Vol. 2 (1892-1901), Vol.3 (1902-1911), and Vol. 4 (1912-1921), Statistical Department of the Inspectorate General of Customs, Shanghai, various years.

[8] Costinot, A., and A. Rodriguez-Clare (2013), "Trade Theory with Numbers: Quantifying the Consequences of Globalization", manuscript, March.

[9] Dernberger, R. F. (1975), The Role of the Foreigner in China's Economic Development", in D. H. Perkins (ed.), China's Modern Economy in Historical Perspective (Stanford, CA: Stanford University Press. 
[10] Donaldson, D. (2015), "The Railroads of the Raj", American Economic Review, forthcoming.

[11] Eaton, J., and S. Kortum (2002), "Technology, Geography, and Trade", Econometrica 70: 1741-1779.

[12] Fairbank, J. K. (1978), "The Creation of the Treaty System", in D. Twitchett and J. K. Fairbank (eds.), The Cambridge History of China, Vol. 10 Late Ch'ing, 1800-1911, Part I (Cambridge: Cambridge University Press).

[13] Fajgelbaum, P., and S. Redding (2014), "External Integration, Structural Transformation and Economic Development: Evidence from Argentina 18701914", NBER Working Paper \# 20217, June.

[14] Findlay, R., and O'Rourke, K. (2007), Power and Plenty: Trade, War, and the World Economy in the Second Millennium, Princeton University Press.

[15] Helliwell, J. and G. Verdier (2001), "Measuring internal trade distances: A new method applied to estimate provincial border effects in Canada," Canadian Journal of Economics 34 (4):1024-1041.

[16] Head, Keith and Thierry Mayer (2001), "Increasing returns versus national product differentiation as an explanation for the pattern of US-Canada trade," American Economic Review 91 (4):858-876.

[17] Head, K., \& Mayer, T. (2002). Illusory Border Effects: Distance mismeasurement inflates estimates of home bias in trade (Vol. 1). Paris: CEPII.w 55(1): 131-168.

[18] Hsiao, L.-L. (1974), China's Foreign Trade Statistics, 1864-1949 (Cambridge, MA: Harvard University Press.

[19] Jia, R. (2014), "The Legacies of Forced Freedom: China's Treaty Ports", Review of Economics and Statistics, vol. 96, 596-608. 
[20] Keller, W., B. Li, and C. H. Shiue (2013), "Shanghai's Trade, China's Growth: Continuity, Recovery, and Change since the Opium Wars", IMF Economic Review Vol. 61(2): 336-378.

[21] Keller, W., B. Li, and C. H. Shiue (2012), "The evolution of domestic trade flows when foreign trade is liberalized: Evidence from the Chinese Maritime Customs Service", in Institutions and Comparative Economic Development, M. Aoki, T. Kuran, and G. Roland (eds.), Palgrave Macmillan.

[22] Keller, W., B. Li, and C. H. Shiue (2011), "China's Foreign Trade: Perspectives From the Past 150 Years", World Economy: 853 - 892 .

[23] Keller, W., and C. H. Shiue (2015), "Capital Markets and Colonial Institutions in China", paper presented at the China Economic Summer Institute conference, Beijing, August 2015.

[24] Kose, H. (2005), "Foreign Trade, Internal Trade, and Industrialization: A Statistical Analysis of Regional Commodity Trade Flows in China, 19141931, in K. Sugihara (ed.), Japan, China, and the Growth of the International Asian Economy, 1850 - 1949 (New York: Oxford University Press), 198-214.

[25] Kose, H. (1994), "Chinese Merchants and Chinese Inter-port Trade", in Japanese Industrialization and the Asian Economy, A. J. H. Latham and H. Kawakatsu (eds.), New York: Routledge.

[26] Krugman, P. M. (2010), "The New Economic Geography, now Middle-aged", paper presented to the Association of American Geographers, April 16, 2010.

[27] Liu, Ta-Chung, and Kung-Chia Yeh (1965), The Economy of the Chinese Mainland: National Income and Economic Development, 1933-1959, Princeton, New Jersey: Princeton University Press.

[28] Lyons, T. (2003), China Maritime Customs and China's Trade Statistics, 1859-1948, Willow Creek Publisher. 
[29] Mitchener, K. J., and S. Yan (2014), "Globalization, trade, and wages: What does history tell us about China?", International Economic Review 55(1): 131-168.

[30] Morse H. (1926), The Chronicles of the East India Trading Company, 16341834, Vols 1-5, Oxford: Clarendon Press.

[31] O'Rourke, K., J. Williamson (1999), Globalization and History. The Evolution of a Nineteenth-Century Atlantic Economy, MIT Press.

[32] O'Rourke, K., J. Williamson (1994), "Late 19th Century Anglo-American Factor Price Convergence: Were Heckscher and Ohlin Right?", Journal of Economic History 54: 892-916.

[33] Perkins, D. H. (1969), Agricultural Development in China 1368-1968, Aldine.

[34] Redding, S. and A. Venables (2000), "Economic geography and inequality," mimeo London School of Economics.

[35] Ramondo, N., A. Rodriguez-Clare, and M. Saborio (2016), "Trade, Domestic Frictions, and Scale Effects", forthcoming, American Economic Review.

[36] Richardson, P. (1999), Economic Change in China, c. 1800-1950. Cambridge University Press.

[37] Shiue, C. H., and W. Keller (2007), "Markets in China and Europe on the Eve of the Industrial Revolution", American Economic Review 97, 4: 1189 1216.

[38] So, B. K. L., and R. H. Myers, eds., (2011), The Treaty Port Economy in Modern China: Empirical Studies of Institutional Change and Economic Performance, China Research Monograph 65, Institute for East Asian Studies, University of California, Berkeley.

[39] Tinbergen, J. (1962), Shaping the World Economy: Suggestions for an International Economic Policy. New York: Twentieth Century Fund. 
[40] Wei, S. J. (1996), "Intra-national versus international trade: How stubborn are nations in global integration?" National Bureau of Economic Research Working Paper no. 5531.

[41] Wolf, H. (1997), "Patterns of intra- and inter-state trade." National Bureau of Economic Research Working Paper no. 5939.

[42] Wolf, H. (2000), "Intranational home bias in trade," Review of Economics and Statistics 824 (4): 555-563. 
Wages are obtained as a mean residual, by port, from an OLS regression on occupation fixed effects, year fixed effects, length of work time fixed effects (hour, month, year), currency fixed effects. The wage for Hankow and Foochow is estimated as the prediction from a regression of observed wages on latitude and longitude. The following, Table 7, shows the different occupations that are available from the Decennial Reports.

Table A1-Wage Data from the Decennial Reports

\begin{tabular}{cccc} 
Region & Obs. & Occupation & Obs. \\
\hline Amoy & 1 & General, skilled (e.g. mechanic) & 21 \\
Canton & 29 & General, unskilled & 19 \\
Chefoo & 30 & Carpenter & 62 \\
Chinkiang & 91 & Stonemason & 57 \\
Foochow & n/a & Painter & 4 \\
Hankow & n/a & Blacksmith & 34 \\
Ichang & 15 & Coolie & 19 \\
Kiaochow & 12 & General, manual & 24 \\
Kiukiang & 8 & Servant & 23 \\
Newchwang & 2 & Cotton/silk weaver & 9 \\
Ningpo & 8 & Matchmaker & 1 \\
Swatow & 10 & Tailor & 26 \\
Shanghai & 12 & Farmhand & 4 \\
Tientsin & 69 & & \\
Wuhu & 7 & & \\
Total & 294 & &
\end{tabular}

Note: Notes: Data from CMC (2001b), Decennial Reports, various volumes; number of observations for 1901-1911: $\mathrm{n}=56,1912-1921: \mathrm{n}=105$, and 1922-1931: $\mathrm{n}=144$.

Appendix B: LABOR FORCE AND GRoss PRODUCT DATA

To obtain figures for the labor force of each region, we employ the average of the population estimates of the Decennial Reports (CMC 2001b) for 1901 and 1911; there are separate estimates for the Chinese and the foreign population, which we add together. We apply Liu and Yeh's estimate of national labor force 
participation in 1933 of $51.8 \%$ to obtain regional labor forces, $L_{i}$ (Liu and Yeh 1965, p. 182). The wage estimates from Appendix A times these labor forces yield a region's wage income, $w_{i} L_{i}$.

Recall that our regions are defined on the basis of the customs districts of the treaty ports. While the ports were of central importance, it would be an overstatement to treat the customs districts as exclusively urban areas. In order to capture the large contribution of agriculture to China's gross product at this time, we estimate the gross product of each region by augmenting the wage income $w_{i} L_{i}$ with an estimate of the region's agricultural production, based on Perkins (1969). The value of agricultural production in each province is estimated for the years 1914-1918 from data on acreage for barley, corn, cotton, fiber (including jute, hemp, ramie, and flax), millet, peanuts, rice, sesame, sorghum, soybeans, sugarcane, tobacco, and wheat (Perkins 1969, Appendix C); yield data for these crops, see Perkins 1969, Appendix D, and crop prices given in Perkins (1969, Table D.31). Given the value of agricultural production in each province, $p_{i} Q_{i}$, we estimate each region $i$ 's agricultural production, $p_{i} Q_{i}$, as $p_{i} Q_{i}=s_{i} \times p_{p} Q_{p}$, where $s_{i}$ is the fraction of region $i$ 's population of the population in the province in which region $i$ is located. The gross product of region $i, Y_{i}=w_{i} L_{i}+\lambda \times p_{i} Q_{i}$, with $\lambda=1.1$ in the baseline analysis. We have confirmed that our main findings are not sensitive to choosing other reasonable values for $\lambda$ (results available upon request).

\section{Appendix C: Purchases-From-Self}

The expenditures of region $i$ on production of $i$ are not observed. We therefore estimate a gravity equation regression of bilateral trade flows on a set of standard gravity covariates to predict the value of each port's consumption of its own goods. These covariates include bilateral distance, the origin and destination ports' respective population sizes, and a dummy variable indicating the destination port's location on the Yangtze River. Values for each of these variables are 
for 1904; however, estimates are also produced including additionally data for the years 1895 through 1899. For these estimates which employ multiple years' worth of data, a time fixed effect is included. To preserve zero trade flows and maintain a sufficiently high sample size after taking logarithms, each trade flow value is increased by one.

Several flexible versions of the gravity equation are employed, including the standard log-linear gravity equation, a Poisson pseudo-maximum likelihood (PPML) estimator of the gravity relationship, and a PPML estimator possessing squared and cubed logarithms of distance. Because of the out-of-sample nature of the predictions, the preferred specifications are ones that are able to most closely fit the relation between bilateral trade flows and distance between ports, i.e., those specifications for which the (joint) significance of the coefficient(s) on distance is suitably high. Finally, each specification is either estimated by pooling the data across all 15 ports, or individually for each port. To capture a realistic measure of internal distance within treaty ports $d_{i i}$, five alternative measures of internal distance from the literature are used for the predictions for purchases-from-self. These include (with $d_{i j}$ denoting the distance between ports $\mathrm{i}$ and $\mathrm{j}$ ):

1) Wei (1996): $d_{i i}=0.25 \min _{j} d_{i j}$,

2) Wolf $(1997,2000): d_{i i}=0.50$ mean $\left(d_{i j}\right)$,

3) Redding and Venables (2000): $d_{i i}=0.33 \sqrt{\operatorname{area}_{i} / \pi}$,

4) Head and Mayer (2000): $d_{i i}=0.67 \sqrt{\operatorname{area}_{i} / \pi}$,

5) Helliwell and Verdier (2001): $d_{i i}=0.52 \sqrt{\operatorname{area}_{i}}$,

where area $_{i}$ denotes the area of the prefecture in which the treaty port $i$ is located. In total, the various specifications and internal distance measures generate $2 \times 3$ x 2 x $5=60$ candidate estimates for purchases-from-self for each of the 15 treaty ports. The preferred estimates are chosen along three dimensions. First, by comparing the correlation between predicted bilateral trade flows $\hat{x}_{i j}$ and observed 
trade flows $x_{i j}$. Estimates with a high correlation do a relatively good job of predicting actual purchases from other ports. For the second and third dimensions, two empirical regularities are exploited: the fact that modern large economies (which in turn tend to be larger exporters) generally have larger magnitudes of consumption of their own goods than smaller economies in absolute terms, and that the ratio of exports to purchases-from-self tends to run from around 0.10 for smaller, isolated countries like Australia, to around 0.25 for the U.S., to 0.35 for large countries such as Germany with many close, large trading partners. We therefore consider as the second dimension the correlation between total trade, $\sum_{j} x_{i j}$, and predicted self-purchases $\hat{x}_{i i}$, and the third dimension as the ratio of total trade to predicted purchases-from-self, $\sum_{j} x_{i j} / \hat{x}_{i i}$. Estimates that perform well in the second and third dimensions, by having, respectively, a high correlation and a "reasonable" ratio, perform comparatively well in predicting the relative magnitude of trade-with-self.

Of the 60 estimates for purchases-from-self, the four best candidate estimates are chosen upon evincing a high degree of performance in each dimension and after fitting the distance variable(s) well: when pooling the data across all ports, they are: i) PPML with a cubic expansion of log distance using Wolf's (1994) internal distance and data for 1904, ii) PPML of standard gravity using Helliwell and Verdier's (2001) internal distance and data for all six years, iii) PPML of standard gravity using Head and Mayer's (2001) internal distance and data for 1904, and with port-level regressions, iv) PPML of standard gravity using Wolf's (1994) distance and data for 1904. 
Table B. Commodity-level price data

\begin{tabular}{|c|c|c|c|c|c|c|}
\hline \multirow[t]{2}{*}{ Commodity } & \multicolumn{3}{|c|}{ Unit price in 1904 (HK taels) } & \multicolumn{3}{|c|}{ Bilateral 1904 price difference (\%) } \\
\hline & Mean & Std. dev. & Std.dev./Mean & Mean & Std. dev. & Std.dev./Mean \\
\hline Sea cucumbers (Bicho de Mar) & 39.48 & 15.36 & 0.39 & 0.38 & 0.29 & 0.77 \\
\hline Blankets and rugs & 0.49 & 0.09 & 0.18 & 0.12 & 0.18 & 1.49 \\
\hline Buttons, brass and fancy & 0.42 & 0.05 & 0.12 & 0.08 & 0.13 & 1.60 \\
\hline Cement & 1.07 & 0.16 & 0.14 & 0.11 & 0.15 & 1.38 \\
\hline Chintzes and plain cotton prints & 2.51 & 0.66 & 0.26 & 0.18 & 0.24 & 1.30 \\
\hline Coal & 5.79 & 0.99 & 0.17 & 0.13 & 0.17 & 1.31 \\
\hline Cotton blankets & 0.80 & 0.29 & 0.36 & 0.40 & 0.29 & 0.73 \\
\hline Cotton thread on spools & 2.43 & 0.24 & 0.10 & 0.09 & 0.13 & 1.36 \\
\hline Cotton yarn & 25.28 & 0.40 & 0.02 & 0.02 & 0.01 & 0.81 \\
\hline Drills & 3.63 & 0.20 & 0.06 & 0.06 & 0.06 & 0.92 \\
\hline Fans, palm-leaf & 0.01 & 0.00 & 0.18 & 0.16 & 0.16 & 0.98 \\
\hline Glass, window & 4.81 & 1.82 & 0.38 & 0.23 & 0.30 & 1.32 \\
\hline Handkerchiefs & 0.45 & 0.02 & 0.06 & 0.06 & 0.05 & 0.80 \\
\hline Hosiery & 1.16 & 0.16 & 0.14 & 0.17 & 0.11 & 0.64 \\
\hline Iron and mild steel, new: bars & 2.91 & 0.37 & 0.13 & 0.08 & 0.14 & 1.77 \\
\hline Iron and mild steel, old & 1.98 & 0.29 & 0.15 & 0.12 & 0.15 & 1.23 \\
\hline Jeans & 3.15 & 0.64 & 0.20 & 0.16 & 0.18 & 1.13 \\
\hline Matches & 0.23 & 0.02 & 0.10 & 0.12 & 0.09 & 0.74 \\
\hline Needles & 0.21 & 0.03 & 0.12 & 0.07 & 0.13 & 1.78 \\
\hline Oil and kerosene & 0.18 & 0.02 & 0.10 & 0.12 & 0.10 & 0.81 \\
\hline Sheetings, grey, plain & 3.34 & 0.28 & 0.08 & 0.08 & 0.08 & 0.95 \\
\hline Shirtings, grey, plain & 2.73 & 0.27 & 0.10 & 0.12 & 0.08 & 0.71 \\
\hline Shirtings, white, plain & 3.92 & 0.03 & 0.01 & 0.01 & 0.01 & 1.02 \\
\hline Soda & 3.13 & 0.33 & 0.11 & 0.12 & 0.10 & 0.86 \\
\hline T-cloths, 32 inches & 1.85 & 0.20 & 0.11 & 0.12 & 0.10 & 0.87 \\
\hline Umbrellas & 0.47 & 0.13 & 0.28 & 0.35 & 0.27 & 0.76 \\
\hline
\end{tabular}

Notes: First three columns report statistics for the unit price of each commodity across ports; columns four to six give statistics on the percentage bilateral price difference (absolute value of price difference over average price in the two ports). Source: CMC (2001a), Vols. 39, 40. 